Article

\title{
Assessment of Citizens' Actions against Light Pollution with Guidelines for Future Initiatives
}

\author{
Karolina M. Zielińska-Dabkowska ${ }^{1, * \mathbb{C}}$, Kyra Xavia ${ }^{2}$ and Katarzyna Bobkowska ${ }^{3}$ \\ 1 GUT LightLab, Faculty of Architecture, Gdansk University of Technology (GUT), 80-233 Gdańsk, Poland \\ 2 International Dark-Sky Association, Tuscon, AZ 85719, USA; kyra.xavia@darksky.org \\ 3 Faculty of Civil and Environmental Engineering, Gdansk University of Technology (GUT), \\ 80-233 Gdańsk, Poland; katarzyna.bobkowska@pg.edu.pl \\ * $\quad$ Correspondence: k.zielinska-dabkowska@pg.edu.pl; Tel.: +48-58-347-2315
}

Received: 30 May 2020; Accepted: 15 June 2020; Published: 18 June 2020

check for updates

\begin{abstract}
Due to the wide reach of media reports about scientific research and technological tools such as the world wide web (WWW), the Internet, and web browsers, citizens today have access to factual information about the negative impact of artificial light at night (ALAN) on their dark skies, and their health and well-being. This means they can now make educated decisions and take the necessary steps to help protect themselves and their communities from disruptive light pollution. Whilst this action is positive and welcomed, unfortunately, according to collected data, not all such initiatives have been successful. Although our understanding of this groundswell movement is deepening, further studies are required to complete a worldwide picture of the current situation. This paper therefore investigates the various actions taken by citizens, as well as the challenges, methods, and tools involved, regarding good practices initiated by grass roots activism on how to reduce existing and potential light pollution. The results of a comparative analysis of 262 international case studies (lawsuits and online petitions) reveal that, since the 1990s, there has been an increase in the number of legal cases related to light pollution due to the rise in public awareness, the availability of scientific knowledge via the Internet, and the ability to take accurate lighting measurements and perform lighting simulations. Also, in the last decade a new tool for digital participation in the form of online petitions has established a new movement of citizen action to mitigate the effects of light pollution. Based on this information, a seven-step framework involving recommendations for citizen action has been developed. It is expected that this new knowledge will benefit those citizens planning future efforts involving the development, implementation, and monitoring processes of outdoor lighting. Additionally, it might support the evolution of planning and policy approaches that are sustainable and necessary to improve the application and installation of ecologically/biologically responsible illumination for towns, cities, and natural habitats.
\end{abstract}

Keywords: light pollution; human health; LEDs; LED lighting; artificial light nuisance; artificial light at night; ALAN; sky glow; public health; citizens' participation; lighting conflicts; lawsuits; online petitions; e-petitions; Campaign to Protect Rural England; CPRE; International Dark-Sky Association; IDA; Earth Hour; International Dark Sky Places Program; grassroots organizations; NASA Earth Observatory images; review

\section{Introduction}

Current studies demonstrate that urban environments in our modern day have continued to become significantly brighter and more illuminated at night, and that man-made light pollution from outdoor illumination that is misdirected, obtrusive, and unwanted has lately increased by more than two percent per year [1]. 
In the past, the first people to notice the unprecedented effects of light pollution were professional and amateur astronomers. They observed that sky glow caused the loss of dark night skies and hindered the ability to view the starscape above. This concern fueled expressions of dismay about light pollution and initiated action against it [2]. As the problem worsened, constellations of stars "vanished" and, most importantly, prevented proper astronomical observations and research. Some 40 years later, environmentalists also became publicly vocal about the negative impact of the use of artificial light at night (ALAN) on the environment, ecosystems, and its inhabiting flora and fauna [3]. Unhealthy patterns were witnessed regarding the avoidance of suitable habitats, alterations in reproduction and seasonal migration routes, as well as the reduction in numbers or even the extinction of certain species. When NASA began to release new, high-definition pictures taken from space at night (Figure 1), the true scale and severity of the problem was revealed [4]. As a consequence of this publicity, many more people became aware of the negative impact of light pollution, the avoidable loss of natural darkness, and the unnecessary disappearance of starry skies at night.

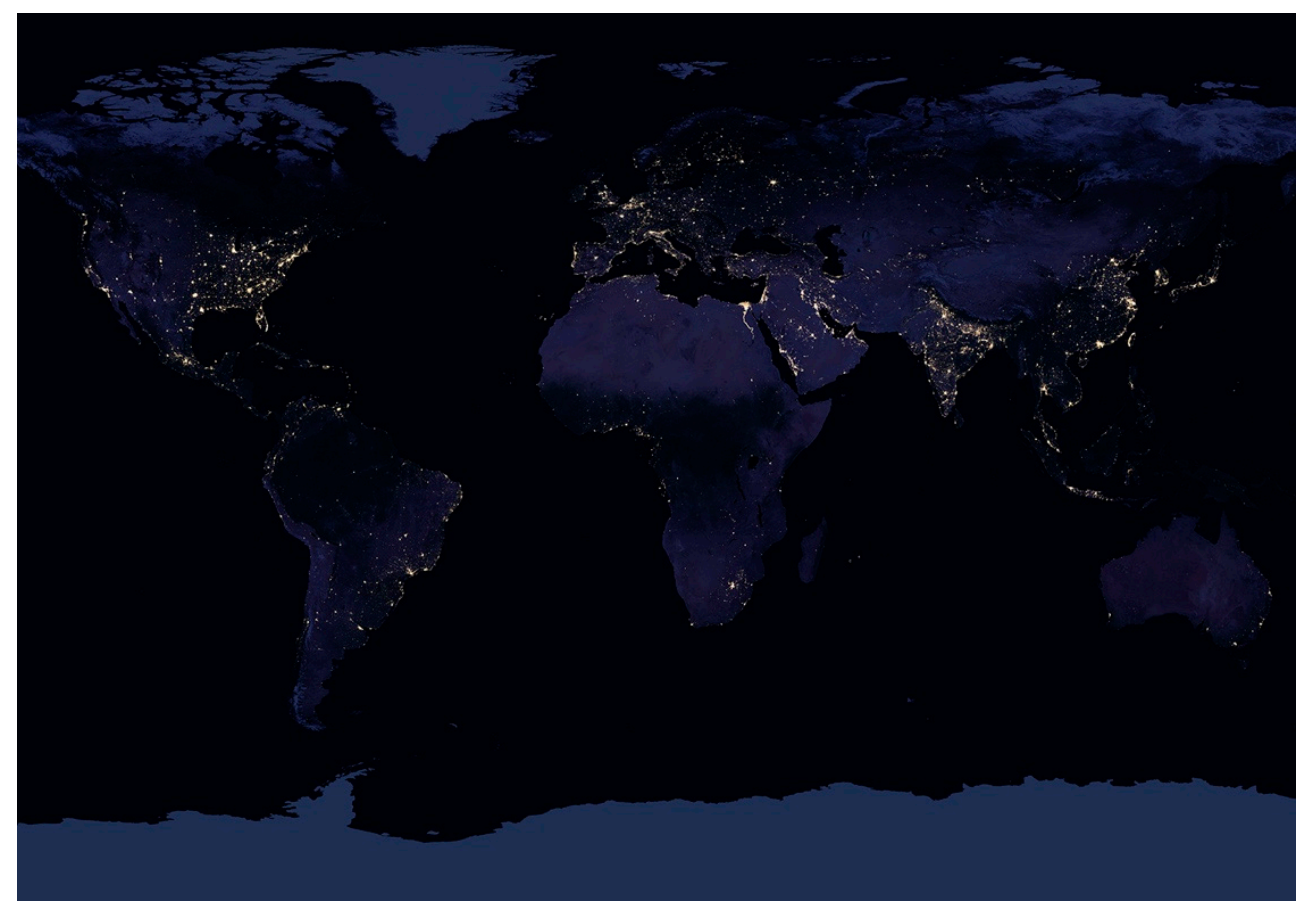

Figure 1. Global map of Earth at night in 2016, showcasing a composite view of the patterns of human settlements across the planet that produce light pollution. Source: NASA Earth Observatory images by Joshua Stevens, using Suomi NPP VIIRS data from Miguel Román, NASA's Goddard Space Flight Center.

Leading up to the present time, researchers have offered some understanding into the body of knowledge of light pollution, from philosophy [5], astronomy [6], ethics [7], measurement [8,9], economics [10], policies [11], regulations [12], medicine [13,14], environmental impact [15], to design challenges [16,17], land protection [18], and more. Regrettably, there is still very little research on the impact of light pollution and its mitigation via citizen participation $[19,20]$. Thus, while enquiry helps to further our understanding of this social shift, more studies are required to complete a worldwide picture of the current situation. Even so, based on the existing case studies presented in this research, it is clear that certain processes are needed to improve the outcome of future actions.

Furthermore, at the turn of the century, significant changes occurred in people's comprehension of how artificial light affects their physiology and the natural environment, revealing the vast complexity of the processes involved, highlighting too, how much more needs to be learned and understood, and how crucial it is to address the problems that have manifested. 
The authors have identified four major contributing factors influencing the formation of citizens' initiatives against light pollution, which are explained in detail in (Figure 2).

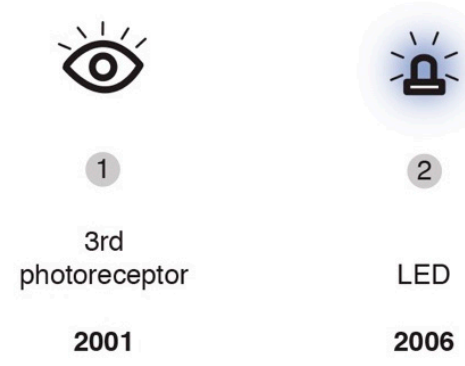

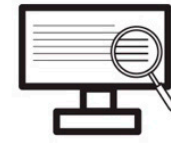

3

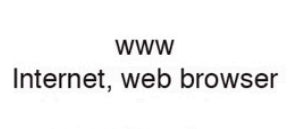

1998 Google

2001 Wikipedia

2002 Linkedln

2004 Facebook

2006 Twitter

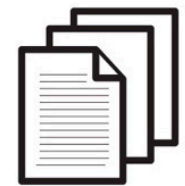

4

AMA

Report

2016

2007 change.org

Figure 2. Four contributing factors driving citizens' initiatives against light pollution: (1) The discovery of a new photoreceptor in the human eye; (2) the development of solid-state lighting (SSL) technology with blue-rich white light-emitting diodes (LEDs); (3) easy access to information about the negative impact of artificial light at night (ALAN) via new technological tools; (4) the American Medical Association's (AMA) published report about their concerns on the use of artificial light at night.

The first factor occurred in 2001, when a new type of photoreceptor was discovered in the human eye, called intrinsically photosensitive retinal ganglion cells (ipRGCs). It is also known as the third photoreceptor because it is different to the two other rod and cone photoreceptors [21]. This paradigm shift radically changed previous assumptions about ocular anatomy because it meant the eyes have another function completely unrelated to vision, namely, they play a crucial role in setting the circadian clock, upon which health depends. This realization also provided new insight into the importance of exposure to natural light during the day [22], as well as the biological need for darkness during the night [23].

Secondly, the development of solid-state lighting (SSL) technology with sources like blue-rich white light-emitting diodes (LEDs) has dramatically changed the way society illuminates spaces indoors and outdoors [24]. Unfortunately, the lighting industry and public authorities have placed too much focus on the technology's energy, operation, and maintenance savings, without due consideration, investigation, and adequate understanding of the broader reaching, long-term costs which far outweigh them. These costs involve the associated numerous inherent drawbacks which negatively impact the environment, ecosystems, and the health of humans, flora, and fauna [25,26]. Further complicating matters, mounting research confirms that commonly used, high intensity LED light sources, with peaks in disruptive blue wavelengths of light, are inappropriate and harmful to most species [27]. The introduction of new light sources should be preceded by detailed research, not only towards new technical, energy saving aspects, but also to observe and understand the impact these new technologies have on human health and the environment.

Thirdly, the last decade has seen a steady rise in the use of the world wide web, the Internet, and web browsers, which have provided easy access to factual information about the negative impact of ALAN on dark skies, and the health and well-being of humans. Furthermore, the dissemination of this knowledge has increased due to online meetings, webinars, and presentations, and through 
professional web-based networks such as LinkedIn. Social media such as Facebook and Twitter have also played a role, as have email and chat messages.

Lastly, in 2016, the publication of a report titled Human and Environmental Effects of Light Emitting Diode Community Lighting [28], by the American Medical Association (AMA), motivated concerned citizens to search for information on the issue, allowing them to form their own opinion on the subject. The AMA report was widely criticized by the American lighting industry and its supporters [29-31] as it disclosed the dangers of using new LED lighting, after more research surfaced questioning this new lighting technology. This controversial information spread, and reputable newspapers interviewed scientists and researchers, effectively "translating" scientific research into information that was comprehensible to the non-scientific community [31-34].

As a consequence of the above, informed members of the public have now become actively involved in disputes against light pollution to try to minimize its impact. They have also begun demanding safer, responsible illumination, generating pressure that requires a response from decision-makers. While action has been undertaken in some countries, official reports of successful initiatives are scarce, hence the author's research into the best methods to help enable effective citizen actions against light pollution.

In order to gain a better overview of the existing situation, the first aim of this study is to create robust science-informed data about the various methods citizens undertake [35] to resolve light pollution disputes. To further support this aim, it seems essential to establish a simple but effective framework which provides inputs on how to deal with the complexity of these lighting related disputes with an easy to follow, step by step process (framework). This new knowledge should assist those planning to take action to improve outdoor lighting in regards to the development and implementation of monitoring processes. Furthermore, this research may also support the evolution of sustainable planning and policy approaches necessary in the application and installation of biologically/ecologically responsible illumination for towns, cities, and natural habitats.

This paper is organized into eight sections. Section 1 places the study in a broad context and highlights why it is important. A literature review of previous work is included, as is a description of how the current study fills the knowledge gap that exists. Section 2 determines the context and impact of the research being performed, by assembling the following factors: Existing background information on light pollution including categories of lighting type nuisance; organizations and their initiatives campaigning against light pollution; the various actions taken by citizens; recommendations on how to measure and minimize light pollution. Section 3 defines the research hypotheses. Section 4 describes the methods (data collection and generation) and protocols (data analysis) applied in the study. Section 5 provides a precise description and summary of the findings about actions that oppose light pollution, which are arranged in a logical sequence. Section 6 discusses the findings and their implications, and explains how they can be interpreted via their perspective of the working hypotheses. Section 7 provides the study's limitations. Section 8 gives a synthesis of the key points and recommends new areas for future research and action in the field of public participation connected to the mitigation and prevention of light pollution.

\section{Background Research}

Wide-ranging background research was commenced for a period of six months. This inquiry involved an in-depth assessment of published information on external lighting and light pollution that included: Books, scientific research papers, lighting standards, regulations and environmental reports, legal documents of existing case studies, media reports found online, as well as the conduction of in-depth interviews with environmental experts and light pollution activists involved in light pollution disputes. Moreover, the authors have included insights and evidence provided by their previous professional research and hands-on experience based on the following roles: Member of International Dark-Sky Association (IDA) Technical Committee, IDA Delegate, and activism by the leader of the Dunedin Dark Skies Group, all of which involves ongoing work to mitigate light pollution. 


\subsection{Light Pollution and its Impact}

Light pollution (LP) is a broad term, and the International Commission on Illumination has yet to agree on a definition to describe the adverse effects of artificial light on the night-time natural environment that also impacts flora, fauna, and humans [36]. Despite this lack of information, some researchers have recognized four distinct forms of LP [37] connected to quantitative, directional, or spectral light attributes, which include: (1) Man-made sky glow; (2) glare; (3) light trespass, and (4) overlighting. As identified below, each source of disturbance might have different effects.

\subsubsection{Man-Made Sky Glow—The Brightening of the Night Sky Over Inhabited Areas}

Man-made sky glow is caused by man-made sources of radiation (e.g., artificial outdoor lighting) and includes radiation that is emitted directly upwards and radiation that is reflected from the surface of the Earth [38]. The use of unfit for purpose, poorly installed street and area lighting can negatively impact the Earth's atmosphere and hinder/prevent astronomical observations (Figure 3). This includes decorative and security building lighting equipment, floodlights on high masts at sports facilities, as well as event, landscape, and advertisement lighting that directs unwanted light into the night sky. Colorful, bright industrial lighting that radiates through glass roofs and the façades of greenhouses into the night sky can also negatively impact astronomical observations [39]. Likewise, the glow above greenhouses can cause visual annoyance at ground level for residents and visitors. (This is why such greenhouses require the installation of blinds.) Sky glow created by cities and towns can even impact terrestrial and aquatic organisms far away from the actual source of light pollution $[40,41]$.

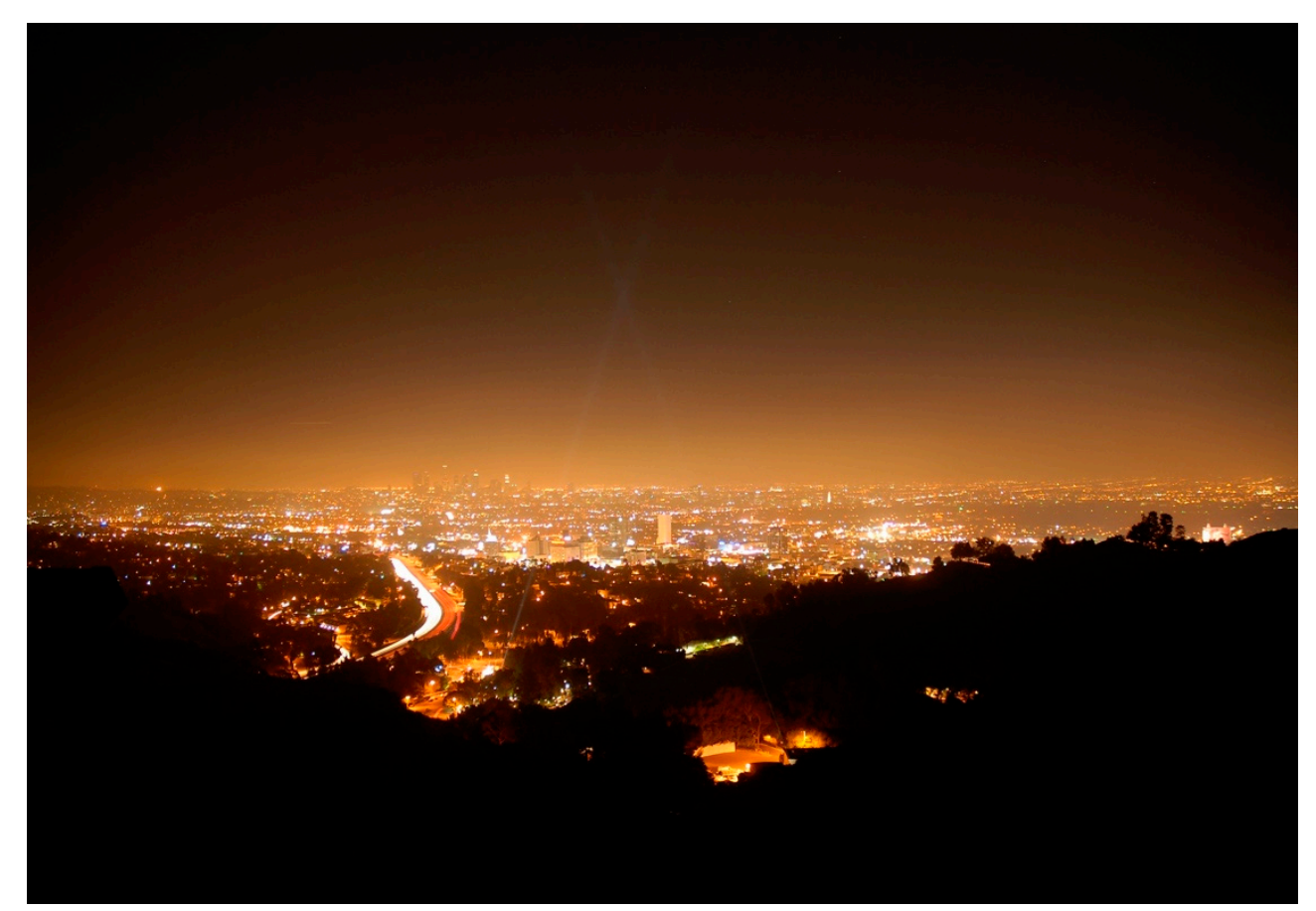

Figure 3. A typical city with a common problem: Man-made orange colored sky glow produced by high-pressure sodium light sources. Those cities that have retrofitted LEDs may have sky glow that is white in color. Source: Mike Knell/Flickr.

\subsubsection{Glare-Excessive Brightness that Causes Visual Discomfort}

Glare is an unpleasant sensation produced by bright areas within the field of vision which can negatively impact the visual perception of humans. Discomfort glare is a result of viewing an intense light source (a poorly placed and/or unshielded luminaire). It can cause annoyance, fatigue, and even pain to residents and visitors. Whereas disability glare impairs the perception of objects without 
necessarily causing discomfort, but due to a reduction in visibility, can cause annoyance, distraction, or a reduction in the ability to see essential information when driving, walking, and cycling, and may contribute to accidents and injury (Figure 4).

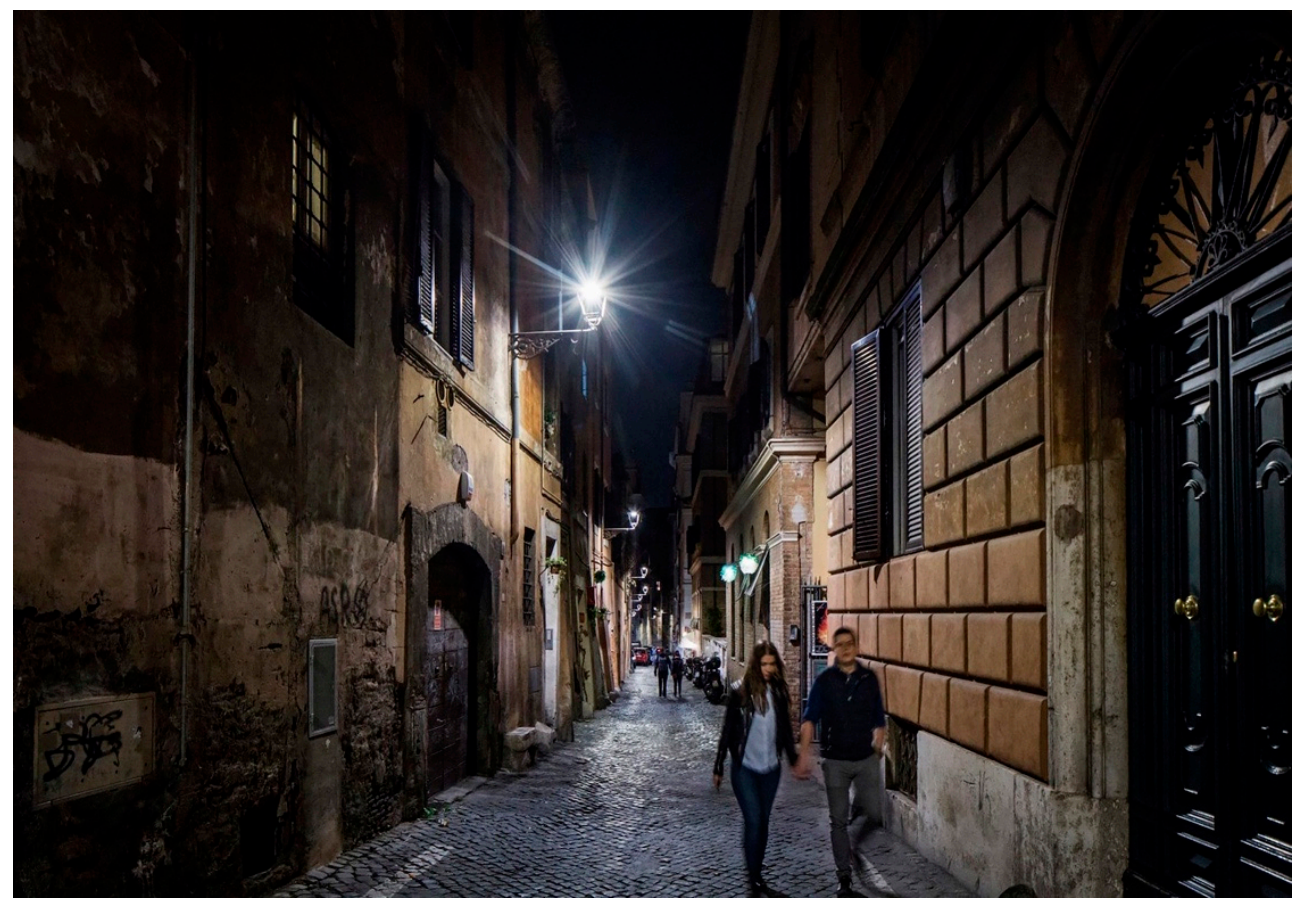

Figure 4. Discomfort glare produced by bright white LED light source, experienced by the pedestrians of Rome, in Italy. Source: Gianni Cipriano/New York Times/Redux/eyevine.

\subsubsection{Light Trespass/Light Spill—Light that Shines Where It Is Unnecessary or Unwanted}

Light trespass, also known as light spill or light intrusion, can negatively impact the evening use, enjoyment, and privacy of residential buildings when light from the exterior intrudes into private living rooms, kitchens, balconies, terraces, and gardens. The unfavorable encroachment of light into bedrooms through windows can also negatively impact the quality and duration of human's nighttime sleep, both critical for health and well-being (Figure 5). Light trespass, for instance, can be from lighting that is positioned too close to a building and on street poles which are too high for residential areas, and/or from decorative building illumination, security, sport facility lighting, and/or advertising. When buildings are over lit and illuminated by vibrant, colorful dynamic lighting, it is not only a source of visual disturbance, it can also ruin the character, ambience, and atmosphere of a place [42].

Additionally, dynamic changes in color and brightness can cause traffic accidents due to the distraction they cause. Light trespass is known to negatively impact fauna, especially when inappropriate illumination from glazed buildings acts as an unnatural source of attraction and becomes a physical barrier to migrating birds [43]. Street, sport facility, and event lighting can also cause disorientation and disruption to the biological rhythms of many species, as well as reduce the quality of habitats for birds, insects, bats, turtles, etc.

Furthermore, the inappropriate illumination of structures like bridges can cause numerous problems. For example, the light from a bridge can reflect off the surface of nearby water. It can also penetrate deep into the water, negatively impacting fish and other living organisms [44]. This disruption reduces biodiversity and harms the food chain by adversely interrupting various crucial behavioral patterns including navigation, foraging, mating, rest, and predation. Light trespass can also negatively impact flora (delaying the loss of foliage, accelerating branch growth, and producing a second bloom in autumn) [45]. 


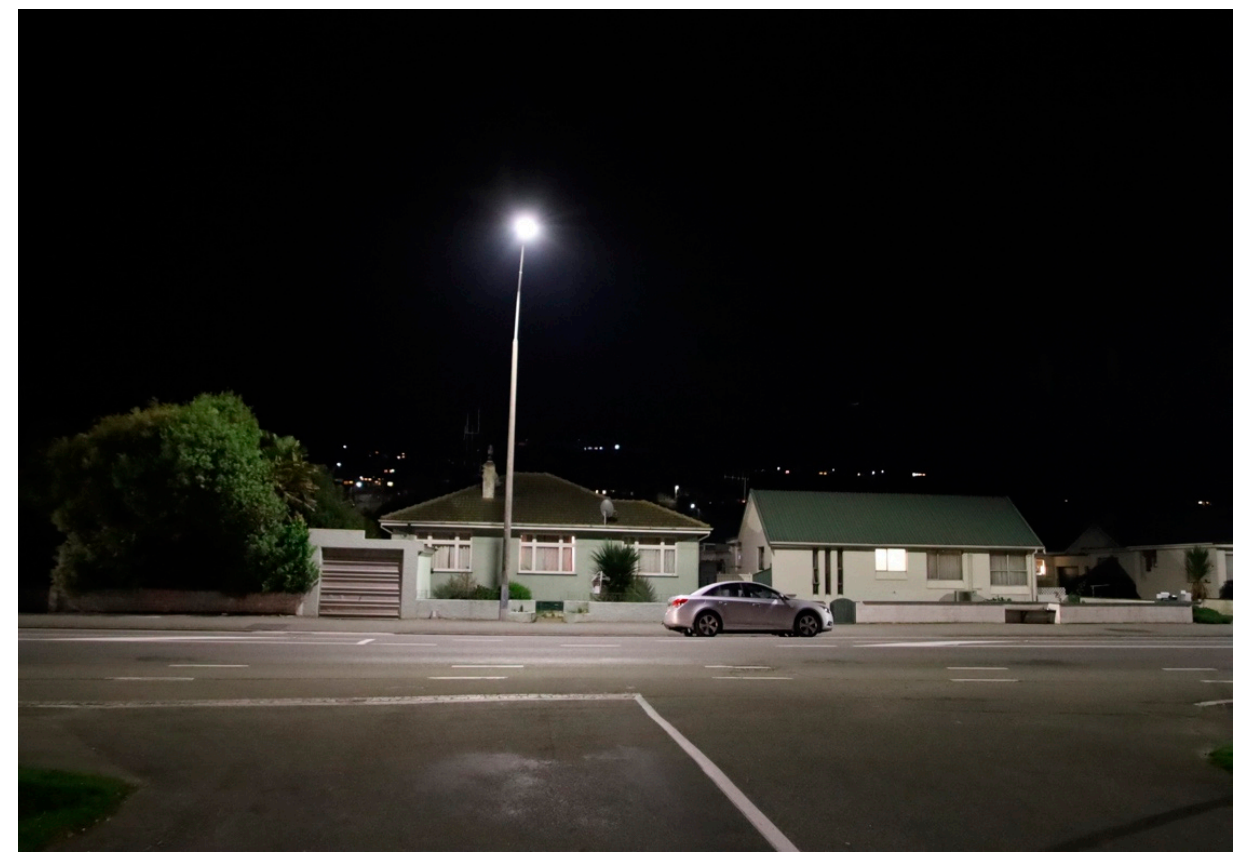

Figure 5. Light trespass/light spill from unshielded $4000 \mathrm{~K}$ LED street lighting entering the windows of residential properties in Oamaru/NZ. Source: Damien McNamara.

\subsubsection{Over-Illumination-The Excessive Use of Light}

Over-illumination is caused by the excessive use of artificial lighting well outside the necessary visual requirements for a specific functional activity and/or aesthetic aspects defined by lighting standards and norms (Figure 6). It can also be created by improper lighting maintenance such as when lighting is not switched off or dimmed throughout the night. (Without the use of timers, occupancy sensors, and lighting controls, energy will also be wasted.)

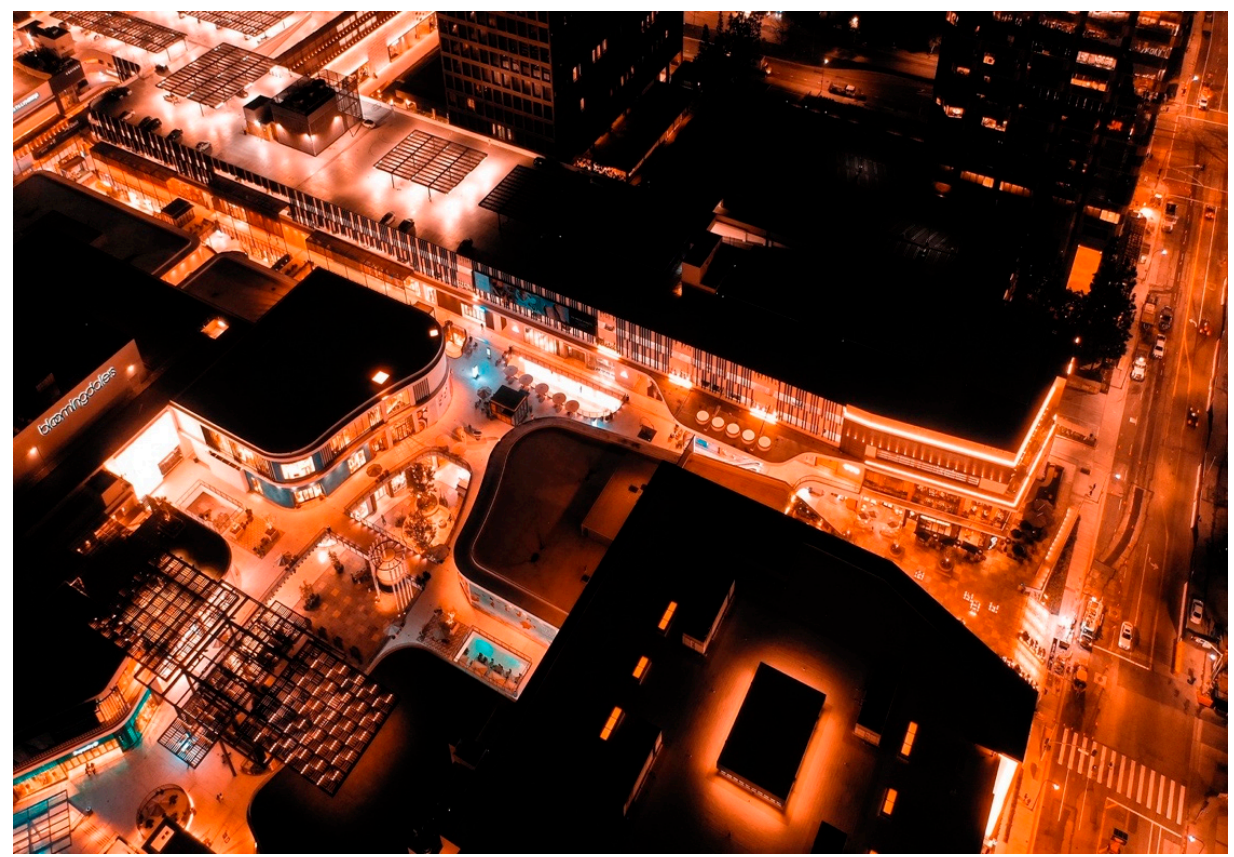

Figure 6. Over-illumination created by the excessive use of artificial lighting well outside the necessary visual requirements, at the Westfield shopping mall in Los Angeles/US. Source: Alonso Reyes/Unsplash. 
This type of nuisance can disturb astronomical observations, and can also be a hazard to vehicular and pedestrian traffic due to the creation of high levels of lighting contrast. Furthermore, over-illumination can also impair the nighttime sleep of citizens, as well as the healthy function of local flora and fauna.

\subsection{Artificial Light at Night Nuisance-Categories of Lighting Types}

Most unwanted light pollution (which is recognized as a major cause of disturbance and discomfort for many people), results from incorrectly designed outdoor artificial lighting (a light source which is in an inappropriate place, that emits an inappropriate amount and type of light, at an inappropriate time, in the wrong direction, see Section 2.1.1). Based on the performed research and analyzed cases, the authors have confirmed eight existing categories of lighting types (Figure 7). Each of these categories can be a major source of disturbance, causing artificial light at night nuisance: (1) Street and area lighting; (2) building and nonbuilding structure lighting; (3) industrial and commercial lighting; (4) sports field facility lighting; (5) advertisement lighting; (6) park and garden lighting; (7) safety and security lighting, and (8) event lighting.

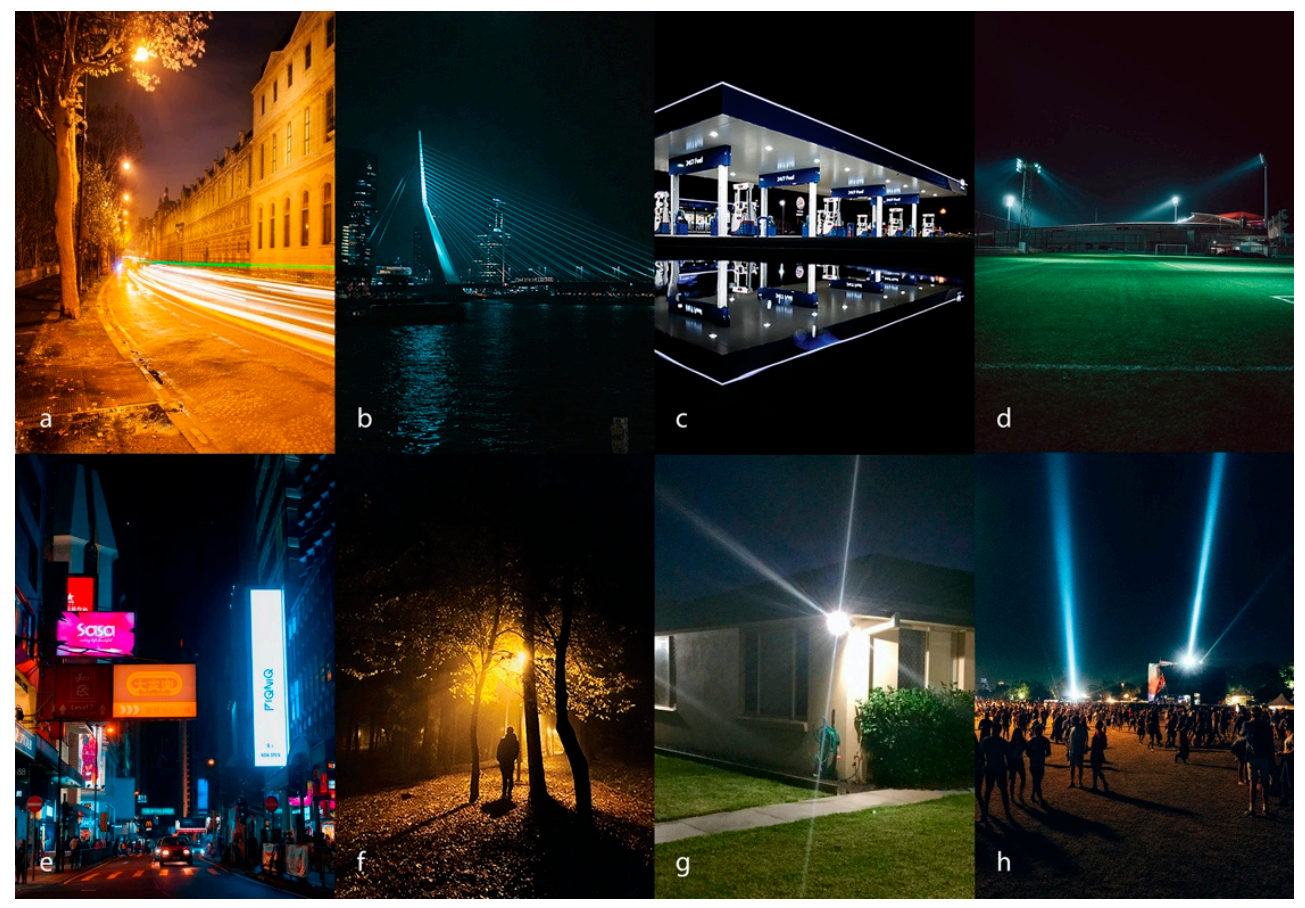

Figure 7. Eight categories of lighting types responsible for artificial light at night nuisance: (a) Street and area lighting; (b) building and nonbuilding structure lighting; (c) industrial and commercial lighting; (d) sports field facility lighting; (e) advertisement lighting; (f) park and garden lighting; (g) safety and security lighting, and (h) event lighting. Sources: (a) Christian Muller/Fotolia, (b) David Benes/Unsplash, (c) Will Li/Unsplash, (d) Marvin Ronsdorf/Unsplash, (e) Lu Avimitin/Unsplash, (f) Gabriela Torzsa/Unsplash, (g) Dean Jones, (h) Tomek Baginski/Unsplash.

\subsection{Organizations and Initiatives Campaigning against Light Pollution}

At the end of XX-century, grassroots activism for responsible illumination came into existence due to the urgent need to mitigate light pollution. These efforts to protect the nighttime environment by informing/educating the public about the use and application of quality artificial lighting have paid off. Today, there are numerous active organizations and initiatives around the world which are already safeguarding the nighttime sky for future generations to come. The authors point out that the most significant of them listed as follows, emphasize the importance of working with citizens on a close basis. 


\subsubsection{Grassroots Organizations}

The Campaign to Protect Rural England (CPRE) is one of the oldest and largest charitable environmental organizations based in the UK. Established in 1926, it now has over 40,000 members and supporters [46]. (It was previously known as the Council for the Preservation of Rural England and the Council for the Protection of Rural England.) One of their aims is to protect and improve dark skies by preventing the spread of unnecessary artificial light. The CPRE charity believes that darkness at night is one of the key features of rural areas so it makes a key differentiation between urban and rural zones. CPRE gives local councils expert advice on planning issues and is known for influencing national and European policies.

The New England Light Pollution Advisory Group (NELPAG) was founded in the USA in 1993. It provides professional support and resources to help improve issues with obtrusive lighting, facilitating the implementation of state and municipal lighting laws and bylaws, as well as informing the public on the benefits of applying efficient, glare-free exterior night lighting to reduce light pollution [47]. The group is known for organizing and sponsoring meetings in the New England territory for lighting professionals, astronomers, policy makers, journalists, and the general public, to debate the progress of exterior nighttime lighting and to determine appropriate illumination and when to use it.

The International Dark-Sky Association (IDA) is one of the oldest and most recognized grassroots organizations in the world. Its mission is to preserve and protect the nighttime environment and the heritage of dark skies through raising awareness about the importance of darkness at night, and to provide education and guidance about quality outdoor lighting [48]. It was first established in the USA in 1988. Local chapters of the IDA were soon created, then later, international chapters were formed too. Today, there are 50 official IDA chapters worldwide, including more than 20 international chapters that represent five continents. This global network of IDA advocates educating decisionmakers, those in municipalities, and the public in their local communities, about the benefits of protecting the night sky. They also help to draft and create lighting ordinance proposals as well as the enacted ordinances themselves needed to minimize light pollution. Within the IDA organization, a technical committee advises the board of directors on emerging issues of outdoor lighting practices that impact the health of humans and the survival of flora and fauna, and works to create relevant policies to mitigate these issues.

In 2020, the IDA signed an agreement with the Illuminating Engineering Society (IES), a recognized technical and educational authority on illumination in the US, for a strategic collaboration to address the global issue of light pollution that negatively affects our environment and the human condition. This collaboration resulted in the creation of The Five Principles for Responsible Outdoor Lighting which help protect the nocturnal landscape and the night sky [49]. These principles recommend: (1) To use light only if it is needed-all light should have a clear purpose; (2) to use shielding and direct light only where it is needed; (3) to minimize brightness-light should be no brighter than necessary; (4) to use controls such as timers, sensors, and motion detectors to activate, dim, or turn lighting off; (5) to minimize the amount of shorter wavelength (blue-violet) lighting and to favor the use of warm color temperature of light or less.

The Commission for Dark Skies (CfDS), previously known as the Campaign for Dark Skies, is an anti-light pollution campaign group based in the UK that was first established in 1989 [50]. Comprised of a network of local officers (and other members), their aim is to improve lighting in their area by providing guidance and advice to residents. The CfDS is run by the British Astronomical Association.

The Light-Pollution Abatement Committee (LPA Committee) was established by the Royal Astronomical Society of Canada in 1991 to implement and maintain actions to reduce light pollution by raising public and government awareness [51]. The members of the committee work on social and legislative transformations that encourage responsible outdoor lighting practices and the conservation of the nighttime environment. They also form coalitions with like-minded groups and organizations. 
CieloBuio — coordination for the protection of the night sky (CieloBuio-coordinamento per la protezione del cielo notturno) is a non-profit organization established in Italy in 1997. Its aims involve protecting the night sky by raising public awareness about the phenomenon of light pollution and supporting the use of eco-friendly artificial lighting [52]. Between 2000-2009, eight regional light pollution laws were created by members of the organization that included professional and amateur astronomers, environmentalists, and lighting professionals.

The National Association for the Protection of the Night Sky and Environment (fL'Association nationale pour la protection du ciel et de l'environnement nocturnes-ANPCEN), formerly known as the National Association for the Protection of the Night Sky (ANPCN), is a French association that works to preserve and protect the quality of the night sky by campaigning against light pollution [53]. Founded in 1999 by astronomers, then further supported by naturalists, researchers, lighting professionals, and policy makers, it has evolved to encompass a broader consideration of the challenges of light pollution which now includes biodiversity and landscapes, health and social issues, energy, climate, and waste etc. This association also advises citizens and communities on light pollution issues.

Dark Skies Advisory Group (DSAG) was founded in 2009 in Switzerland, to offer advice and assistance in the best interests of the International Union for Conservation of Nature (IUCN) to other organizations in regards to light pollution and dark sky principles [54]. The DSAG specifically relate to the ecological integrity, guest gratitude, and public appreciation of protected areas, and the long term conservation of dark sky values for generations to come. In joining with the IUCN's as an advisory body to the World Heritage Convention, the members guide, evaluate, and make suggestions to the IUCN Secretariat in regards to World Heritage studies and submissions that address or touch upon dark skies and light pollution. The group consists of members of the Urban Conservation Strategies Specialist Group who offer their free time, and answer requests for advice from individual citizens and organizations.

The Australasian Dark Sky Alliance (ADSA) is a non-profit organization established in Australia in 2019 to increase awareness about the negative impact of artificial light at night by educating the public and policymakers about night sky conservation [55]. The ADSA also promotes environmentally responsible outdoor lighting, provides advice on the installation of new lighting systems (and the upgrading of existing lighting), and assists in the designation of IDA Dark-Sky Places. The ADSA Approved Luminaires label conforms with dark sky principles specific to Australasian standards and guidelines which are considerate of the night sky, ecosystems, wildlife, human health, well-being, and visual comfort.

\subsubsection{Initiatives to Mitigate Light Pollution}

In 1991, the Royal Astronomical Society of Canada (RASC) created its Light-Pollution Abatement (LPA) Program [56] to reduce unnecessary glare, light spill, and trespass. Meetings are encouraged at the local level between residents, businesses, government, and the media, to raise awareness about the problems created by light pollution and to spread the word about various solutions, which include practical recommendations to reduce obtrusive lighting. The program is managed by volunteers on the RASC LPA Committee, across Canada.

Fatal Light Awareness Program (FLAP) Canada is a program to help mitigate light pollution founded in Toronto, Canada, in 1993. This grassroots community organization is focused on safeguarding migratory birds in the built environment through the following actions: Education, policy development, research, rescue, and recovery. The registered Canadian charitable society is widely recognized as the authority on the prevention of bird-building collision. In 2010, FLAP's knowledge and advocacy work helped create the BirdSafe Building Standard for Mitigating Night-time Bird-Building Collisions. This standard provides guiding principles to help reduce the potential for bird-building collisions at new and existing buildings [57].

International Dark Sky Places (IDSP) is a conservation program developed by the IDA in 2001 that aims to recognize and protect locations of exceptional nighttime features for future generations, and to 
encourage mindfulness about the issues involved [58]. It motivates communities, parks, and protected areas around the world to preserve and protect dark sites through sensible lighting policies and public education. There is a demanding application process that requires candidates to demonstrate robust community support for dark sky protection, as well as adherence to document designation-specific program guidelines. There are already 130 certified IDSPs in the world.

National Dark-Sky Week (NDSW) began in the USA in 2003, and is held during the week of the new moon in April, during which, people worldwide switch off their lighting in order to observe the magnificence of the night sky without light pollution [59]. In 2020, the event was held online to celebrate the night and allow people around the globe to learn more via virtual engagement with authors, scientists, and educators, all with the goal of safeguarding the night from light pollution.

NightBlight is an initiative created by the CPRE in 2003, for mapping England's light pollution and dark skies [60]. Thanks to the Geographic Information Systems (GIS) data collected by the United States National Oceanic and Atmospheric Administration (NOAA) Suomi NPP satellite, an interactive map was created in 2016, to highlight the patterns of light pollution around the UK, as well as to identify those areas with the darkest skies [61]. NightBlight also includes practical and helpful information for local authorities, counties, regions, designated landscapes, and National Character Areas in the form of PDF maps, as well as providing a summary of statistical data.

In 2005, a voluntary program called Lights Out began in New York City. Its goal is to reduce the estimated 600 million birds that perish each year from collisions with illuminated buildings in cities across North America [62]. Thanks to its effectiveness, the program has spread [63]. As part of this program, building owners and managers in participating cities agree to turn off or dim all architectural and indoor lighting between 23:00 and 5:00 during spring and autumn, when birds migrate. Over the years, the buildings involved in this program have saved money, reduced energy consumption, lowered the risk of climate change, and caused less harm to wildlife.

Another worldwide initiative is Earth Hour, organized by the World Wide Fund for Nature (WWF). This occurs annually, on the last Saturday of March, where communities and businesses turn off all non-essential electric lights, for one hour, from 20:30 to 21:30 (Figure 8). This grassroots movement first began in Sydney, Australia, in 2007, as an event where the lights were switched off in the city to raise awareness about climate change and energy consumption. To date, 7000 cities and towns across 187 countries and territories worldwide have become involved [64]. This symbolic action brings awareness about treasuring our planet and the value of unpolluted dark skies (which can be observed during the event and reported by light pollution researchers) [65].

While it has no real direct impact on the natural environment, humans, flora, and fauna because it is too short, there is still a visual and psychological impact which promulgates the importance of the nocturnal landscape.

Established in 2007, a Star Count is another campaign by CPRE to raise awareness about light pollution by including the public in star counting, in order to record the scale of light pollution across the UK in the form of a nationwide survey [66].

The Stars and Villages label (Villes et Villages étoilés) is a program developed by ANPCEN in 2011, for French municipalities. It aims to promote not only best lighting practices to ensure better quality of the night and the nighttime environment, but to also implement laws that help reduce and prevent light pollution. This program, approved by the Ministry of Ecology and Inclusive Transition, has a 1 to 5 star rating system, which can be awarded depending on the level of involvement of the municipality in the management of its night lighting. There are already 574 municipalities in France that have been awarded this label [67].

The International Day of Light was established by the United Nations (UN) on the 16th of May in 2017 [68,69]. It is a yearly celebration offering a podium for sustained appreciation of the significant role that light plays in the lives of citizens around the world. One of its goals is to foster understanding that technologies and thoughtful design can achieve energy efficiency, and the reduction of light pollution, which is one of the fundamental elements for the conservation of dark skies. 


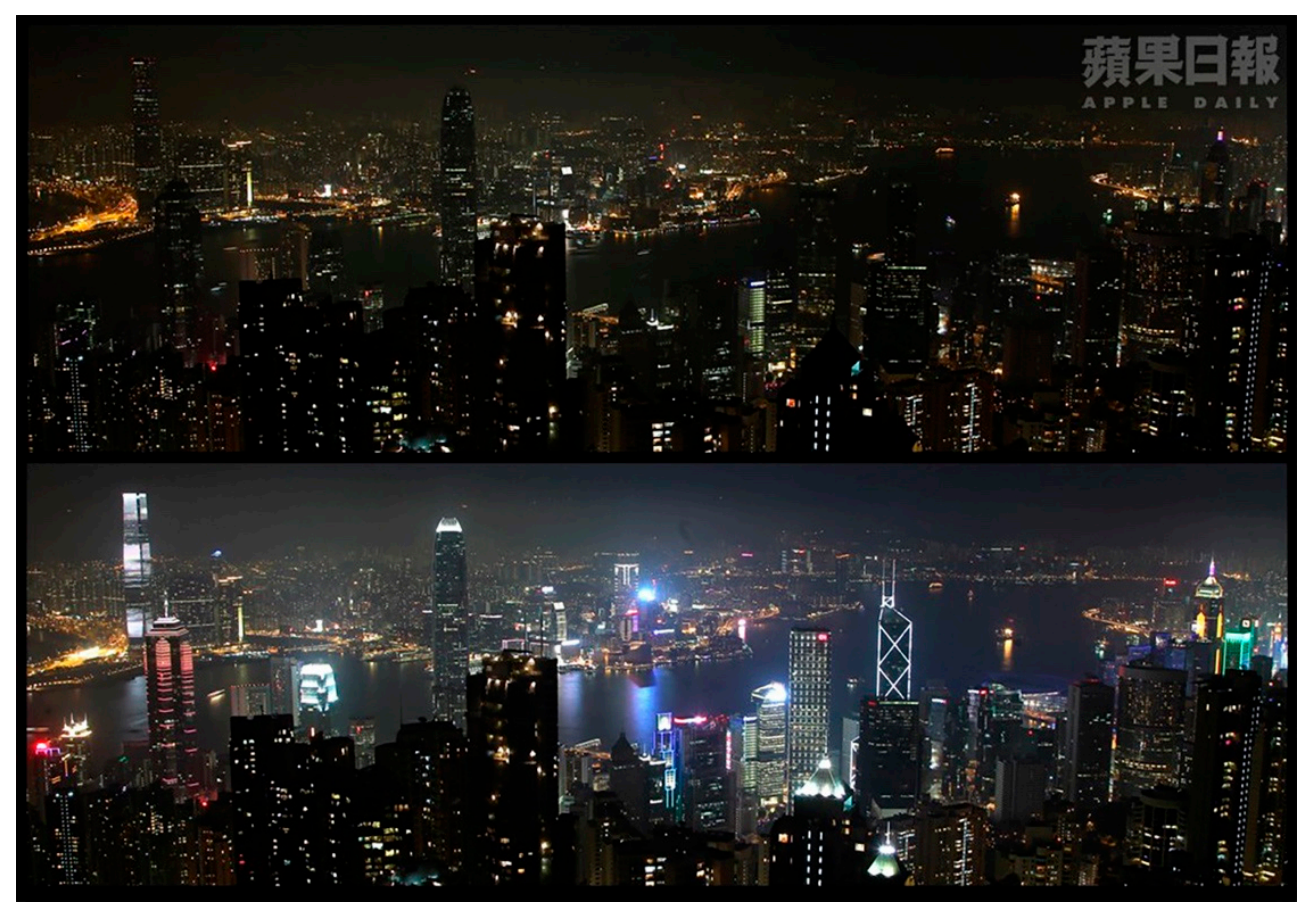

Figure 8. Hong Kong skyline with Kowloon Peninsula and Hong Kong Island at night during Earth Hour in 2013 (top), and after (bottom). Source: Apple Daily's figure.

STARS4ALL was another initiative sponsored by the European Union/European Commission under the Horizon 2020 Program, between January 2016 and 2018, to foster research in Europe and create a collective awareness platform for promoting dark skies [70]. Some of the developments involved the creation of the Dark Sky Meter app, which measures the sky brightness and shares it with scientists around the globe, and also a TESS-W photometer designed to measure and provide continuous monitoring of the night sky brightness for light pollution studies.

The IDA's Criteria for Community Friendly Outdoor Sports Lighting v1.0, published in 2018, helps to improve the design of outdoor sport facility lighting in order to minimize its sky-glow, light trespass, and glare into surrounding residential areas as well as places where local ecology needs to be protected [71].

The IDA's Guidance for Electronic Message Centers (EMCs), published in 2019, specifies minimum requirements and outlines a set of best management practices in order to decrease the negative impact of illuminated signage in built environments [72].

The handbook, Blinded by the Light, published in 2020 by the CfDS, contains some practical suggestions on how to minimize the negative issues of ALAN. It is designed for responsible lighting campaigners advocating against light pollution and those adversely affected by it. It contains three useful appendixes: (1) Lighting assessment principles; (2) a sample letter about poor quality lighting for complainants to use, and (3) simple, non-scientific methods to assess the quality of the night sky [73].

\subsection{Lighting Organizations and Their Recommendations to Measure and Minimize Light Pollution}

Light pollution is acknowledged as a legal concept only in a limited number of countries around the world. In countries where there is no legislation, citizens can refer in their actions, to the following lighting organizations such as: The European Committee for Standardization, the International Commission on Illumination, the Illuminating Engineering Society, and the Institution of Lighting Professionals and their useful documents, which give certain lighting values to be measured, and provide possible ways to handle numerous light pollution issues. 


\subsubsection{The European Committee for Standardization (CEN)}

The European Committee for Standardization (CEN) was founded in Brussels in 1961. It is a public standard organization that brings together the national standardization bodies of 34 European countries [74]. This committee is also responsible for creating the European Lighting Standard, which is a technical document designed to be used as a rule, guideline, or definition. The current European standard EN12464-2:2014 called Light and Lighting-Lighting of Work Places, Part 2: Outdoor Work Places [75], defines requirements to protect the nighttime environment and control the obtrusive light from exterior lighting installations on flora, fauna, and humans. These requirements are based on four environmental zones. Light trespass on windows can be verified by vertical illuminance, glare can be identified by luminaire intensity, sky glow can be determined by the upward light ratio of a lighting installation, and a building's brightness can be perceived by the observer via its luminance (Table 1).

Table 1. Maximum obstructive light permitted for exterior lighting installations. Source: [75].

\begin{tabular}{|c|c|c|c|c|c|c|c|}
\hline \multirow{2}{*}{$\begin{array}{l}\text { Environmental } \\
\text { Zone }\end{array}$} & \multirow{2}{*}{\multicolumn{2}{|c|}{$\begin{array}{c}\text { Light on Properties } \\
E_{v} \\
{[1 \mathrm{x}]}\end{array}$}} & \multirow{2}{*}{\multicolumn{2}{|c|}{$\begin{array}{c}\text { Luminaire Intensity } \\
I \\
{[\mathrm{~cd}]}\end{array}$}} & \multirow{2}{*}{$\begin{array}{c}\text { Upward Light Ratio } \\
\mathbf{R}_{\mathrm{UL}} \\
{[\%]}\end{array}$} & \multicolumn{2}{|c|}{ Luminance } \\
\hline & & & & & & $\begin{array}{c}\begin{array}{c}\mathrm{L}_{\mathrm{b}} \\
{\left[\mathrm{cd} / \mathrm{m}^{2}\right]}\end{array} \\
\text { Building Façade }\end{array}$ & $\frac{\begin{array}{c}\mathbf{L}_{\mathrm{s}} \\
{\left[\mathrm{cd} / \mathrm{m}^{2}\right]}\end{array}}{\text { Sign }}$ \\
\hline E1 & 2 & 0 & 2500 & 0 & 0 & 0 & 50 \\
\hline E2 & 5 & 1 & 7500 & 500 & 5 & 5 & 400 \\
\hline
\end{tabular}

E1 represents intrinsically dark areas, such as national parks or protected sites; E2 represents low district brightness areas, such as industrial or residential rural areas; E3 represents medium district brightness areas, such as industrial or residential suburbs; E4 represents high district brightness areas, such as town centers and commercial areas; $\mathrm{Ev}$ is the maximum value of vertical illuminance on properties in lux; $I$ is the light intensity of each source in the potentially obtrusive direction in cd; RUL is the proportion of the flux of the luminaire (s) that is emitted above the horizontal when the luminaire (s) is (are) mounted in its (their) installed position, and given in $\%$; $\mathrm{L}_{\mathrm{b}}$ is the maximum average luminance of the façade of a building in $\mathrm{cd} / \mathrm{m}^{2} ; \mathrm{L}_{\mathrm{s}}$ is the maximum average luminance of signs in $\mathrm{cd} / \mathrm{m}^{2}$. Curfew is the time after which stricter requirements (for the control of obtrusive light) will apply. It is often a condition in the use of lighting that is applied by the local planning authority. If not otherwise stated-23.00 hrs is suggested.

\subsubsection{The International Commission on Illumination (CIE)}

The International Commission on Illumination (CIE) established in Austria in 1913 is the international authority on light and lighting. The CIE consists of CIE national committees from 40 countries, and more than 15 individual members from countries or regions where there are not yet any national committees. The main goals of the CIE are to create a forum for international discussion on matters related to science, technology, and practice in the field of light and lighting, and to exchange information in this field to create basic standards and procedures for measuring light quantities. In addition, the CIE creates standards to be used when defining the rules and procedures in international and national standards in the field of light and lighting, as well as preparing and issuing standards, recommendations, reports, and other publications related to science, technology, and practice.

The CIE 150: 2017 document titled Guide on the Limitation of the Effects of Obstructive Light from Outdoor Lighting Installations [76], provides guidance for external illumination to reduce the adverse effects of light pollution. It proposes five different environmental zones (E0-E4) determined by their location and use, and also includes different lighting factors. This advice sets acceptable levels for light trespass into windows from a façade, the allowable maximum average luminance of a façade, and also defines levels for sky glow. The CIE also published another document, the CIE 126: 1987, titled Guidelines for Minimizing Sky Glow [77], which gives general guidance for lighting designers and policy makers on the reduction of sky glow. The report briefly discusses the theoretical aspects of sky glow and gives recommendations for the maximum permissible values of lighting installations that take into consideration what is necessary to allow astronomical observations. 


\subsubsection{The Illuminating Engineering Society (IES)}

The Illuminating Engineering Society (IES) was founded in the USA in 1906 as the technical and educational authority on illumination. It aims to improve the lit environment by bringing together those with lighting knowledge and translate that knowledge into actions that benefit the public [78]. The organization has about 8000 members worldwide. This consists of engineers, architects, designers, educators, students, contractors, distributors, utility personnel, manufacturers, and scientists. The Model Lighting Ordinance (MLO) was developed by the IDA and the IES in 2011. It is a tool to help municipalities develop exterior lighting standards that reduce glare, light trespass, and sky glow by applying five lighting environmental zones (LZ0-4) to classify land use with appropriate lighting levels for each of the zones [79].

Additionally, the MLO also incorporates the backlight-uplight-glare (BUG) rating system for luminaires, which delivers an effective mechanism to control unwanted light [80]. The IES RP-33-14 recommended practice (RP) document, titled Lighting for Exterior Environments [81], outlines the environmental considerations of outdoor lighting, especially related to sky glow and light trespass. In addition, this RP provides information on how to assign lighting zones, and how to use the joint IDA-IES Model Lighting Ordinance (MLO) and User's Guide as a basis for an outdoor lighting ordinance.

\subsubsection{The Institution of Lighting Professionals (ILP)}

The Institution of Lighting Professionals (ILP) established in the UK in 1924, is a leading professional lighting engineering body, known for providing advice on a wide range of issues, including legislation and regulations that affect the built environment [82]. Their newest document, GN01, titled Guidance Note 1 for the Reduction of Obtrusive Light 2020 [83], has been updated to include information from CIE 150: 2017. It also provides some useful knowledge about the impact of a light source on the ability to view the night sky that involves the various angles of light that are emitted, and its direct effects on sky glow and glare. Another document, the PLG05, called the Brightness of Illuminated Advertisement [84], provides clear guidance on illuminated advertising signs which, if not properly designed, can create unnecessary glare and light trespass.

\subsection{Citizens' Actions}

Throughout this research, two types of citizens' actions that oppose light pollution were identified: (1) Legal and (2) non-legal. Legal action in the form of civil lawsuits have been known for many years, with the first case connected to the subject identified by the authors as early as 1923 [85], when artificial light started to be widely used outdoors. The dark night sky, which was already brightened by street lighting, soon also became illuminated by high-rise buildings, dynamic advertisements mounted to their façades, floodlights from sports facilities [86], and event searchlights, all of which caused lighting nuisance and increased sky glow. In the past, such legal actions were raised by an individual or groups of citizens [87] or, later on, by businesses such as drive-in theatres that were disturbed by the light trespass from neighboring lighting installations [88]. Lastly, new types of legal cases started to emerge, connected to the environment and health, where groups of concerned citizens filed lawsuits against municipalities who retrofitted existing street lighting with new LEDs $[89,90]$.

At the end of the XX-century, non-legal actions such as face to face lobbying, phone calls, and letter writing campaigns were commonly employed. Before the digital age, the first petitions regarding light pollution were sent via mail delivery. This includes a petition in 1994, to the European Commission Petition Committee by the British Astronomical Associations (BAA) [91]. Today, technology such as the Internet has made it possible to use online services for citizen engagement. Digital participation, known also as e-participation, is explained as "the process of engaging citizens through ICTs in policy and decision-making in order to make public administration participatory, inclusive, collaborative and deliberative for intrinsic and instrumental ends" [92]. 
The online petition, also known as e-petition or Internet petition, is a form of request which is signed online, typically through a form on a specific website. Upon achieving the required number of signatories, the petition letter may be submitted to the recipient of the petition, often by e-mail. The first citizen online petition about light pollution on a web-based petition host was identified in 2012 [93]. Soon after, online petitions were also created on various websites which belong to governments and organizations. Some national governments such as the UK [94], or the German Government [95], allow their citizens to submit an e-petition. In the UK, Members of Parliament (MPs) can present a petition to Parliament on behalf of their constituents. Organizations such as the European Union (EU) has a dedicated online petition site for any individual or organization based in the EU for an issue related to EU policy or law [96].

Furthermore, this study has identified that there are no online petitions websites worldwide dedicated only to light pollution activism.

\section{Hypotheses}

In order to achieve research objectives and examine current citizen initiatives to mitigate light pollution and their influencing factors, the following hypotheses have been developed:

Hypothesis 1 (H1). Since the 1990s, there has been an increase in the number of legal cases related to light pollution due to the rise in public awareness, the availability of scientific knowledge via the Internet, and the ability to take accurate lighting measurements and perform lighting simulations.

Hypothesis 2 (H2). In the last decade, a new tool for digital participation in the form of online petitions, has established a new movement of citizen action to mitigate the effects of light pollution.

\section{Materials and Methods}

This section gives a comprehensive report and clarifies the procedure of data selection and content analysis that was followed in the study to test the research hypotheses.

\subsection{Data Selection}

Accounts of legal and non-legal international citizens' actions connected to light pollution were chosen as an experimental basis, for finding and selecting a wide sample of case studies [97], along with a detailed source of information about current developments. These were chosen using 10 basic criteria: (1) Only case studies representing lawsuits and digital participation should be included; (2) reported actions should be spread worldwide; (3) all cases reported between the beginning of the XX-century to 2019 should be included; (4) the collected examples should increase the diversity of case studies; (5) only light pollution-related cases should be considered, cases requesting light or more light to be excluded; (6) only artificial electric lighting related cases should be considered (gas lighting installations were excluded); (7) only actions taken by citizens are considered (actions taken by towns, countries, and other organizations are excluded); (8) nuisance connected to traffic (car headlights, etc.) are excluded; (9) the reported actions should be documented in satisfactory detail (cases for which data was lacking were consequently excluded); (10) information regarding case studies should be available free of charge. All data was collected between November 2019 to May 2020, in a process that combined various search strategies.

The performed typical keyword-based search method using the words and phrases: "lighting conflicts", "light pollution", and "ALAN conflicts" for scientific research papers on academic platforms such as Web of Science and Scopus yielded no results. Additional searches on Google Scholar identified only two papers that partially discussed the issues. It is anticipated by the authors that this result is due to the fact that the topic of lighting conflicts in relation to light pollution mitigation is quite new. As a consequence, few studies have been published on this particular subject. This suggests that 
this scientific study appears to be particularly significant in recognizing gaps in existing literature. Based on the above outcome, a new search strategy was put in place to identify legal and non-legal actions. First, the legal actions (civil lawsuits) were identified by an organized keyword-search via Internet media articles, environmental reports, and as references of other lawsuits, with an additional 110 cases added, based on research performed in 2017, and provided by Iris Zhou, a Harvard Law School student [98]. Each of the lawsuit cases in the USA were verified on special legal websites: casetext.com, law.justia.com, casemine.com, courtlistener.com, leagle.com that contained the published lawsuits details.

Furthermore, an additional filter was applied by reading the text of the published case study and involved selecting only those case studies which opposed light pollution; cases which demanded more artificial light were excluded. The basic sample was successfully complemented by way of selecting additional cases in languages other than English (German and Polish) on special legal websites: gesetze-bayern.de, www.schweizer.eu, saos.org.pl, orzeczenia.ms.gov.pl, and in online media news, in order to fill an apparent gap and expand the sample's scope. Interviews with light pollution experts were conducted and five additional case studies were added, which were not identified using the previously mentioned search methods. As a result of these actions, a total of 152 recorded lawsuit case studies were selected, with all of these cases occurring between 1923 and 2019.

Secondly, non-legal actions were identified via online petition websites and online versions of newspaper articles. The first set of case studies in online petition websites were collected via an organized keyword-search which consisted of the following words and phrases: "light pollution", "artificial light at night", “ALAN", “dark sky", "sky glow", “LED”, “light obstruction”, “light”, "light trespass", "light nuisance", and "glare". Change.org platform was selected as this is one of the largest online petition sites in the world, having been used by millions of people [99]. This resulted in 102 identified case studies, with five studies excluded due to petitioners requesting more light [100] or making an inappropriate illumination proposal which would cause extensive light pollution [101].

Additionally, a dedicated EU online petition website that was established in 2013 was searched [102]. All petitions appear in the EU portal after the adoption by the Committee on Petitions. After a keyword-search which consisted of the following words and phrases: "light" and "light pollution", this resulted in an additional 20 identified case studies, with 14 studies excluded due to not being directly connected to the topic of light pollution. Additional searches using Google Web Search engine for other online petitions, using search phrase "online petitions against light pollution" identified seven more new cases on the following petition websites: petition.parliament.uk, hertfordshire.gov.uk, gopetition.com, ipetitions.com and avaaz.org.

The final sample which was analyzed, consisted of a total of 110 recorded online petitions case studies which related to eight categories of lighting types being a source of disturbance (see Section 2.2 for a detailed explanation). All of these cases occurred between 2012 and 2019.

\subsection{Data Analysis}

The collected case studies were first examined by a qualitative content analysis (QCA) method $[103,104]$. In order to systematize a larger number of citizens' actions and to obtain viable results, a Microsoft Excel spreadsheet program was employed to record descriptive variables and create a code of categories of data manually, according to the following parameters: Type of action (legal versus non-legal), year, country, number of case studies per year, the achieved case result (success or failure), number of participants per petition, and the current status of the lighting installation - existing versus planned, as well as eight categories of lighting types that create ALAN nuisance.

The second step involved transforming collated qualitative (non-numerical) data into quantitative (numerical) data, for a statistically driven approach and comparison between the number of legal and non-legal actions.

Moreover, a scatterplot [105] was employed to validate two-dimensional data with dots to represent two different variables-one plotted along the x-axis (time/year of action) and the other 
plotted along the y-axis (number of lawsuit cases or e-petitions respectively). This provides a visual reference that reveals how much citizens' actions have increased over time. All non-photographic graph figures were created using Microsoft Excel software.

\section{Results}

The growing uncontrolled use of ALAN in urban and natural settings often forces ordinary citizens to take action to mitigate its negative impact on the environment and to protect their health, well-being, and life quality. Our analysis helped to classify the case studies into three distinct action types: (1) Lawsuits, (2) digital participation/online petitions, and (3) other actions involving various parameters such as the duration of action taken, the difficulty level of the submission (ease of setting up a case), the cost involved, and its effectiveness (Table 2). Due to a lack of access to reliable information, other actions have been excluded from the overall analysis and only estimates are provided.

Table 2. Citizens' actions opposing light pollution. Source: Authors' elaboration.

\begin{tabular}{|c|c|c|c|c|c|c|}
\hline \multirow[b]{2}{*}{ Legal actions } & \multicolumn{2}{|c|}{ Action Type } & \multirow{2}{*}{$\begin{array}{c}\text { Duration } \\
\text { long }\end{array}$} & \multirow{2}{*}{$\begin{array}{c}\begin{array}{c}\text { Difficulty Level } \\
\text { of Submission }\end{array} \\
\text { difficult }\end{array}$} & \multirow{2}{*}{$\begin{array}{c}\begin{array}{c}\text { Cost } \\
\text { Involved }\end{array} \\
\text { yes }\end{array}$} & \multirow{2}{*}{$\begin{array}{c}\text { Effectiveness } \\
\text { medium }\end{array}$} \\
\hline & 1. Lawsuits & $\begin{array}{l}\text { 1a. civil lawsuits } \\
\text { 1b. criminal lawsuits }\end{array}$ & & & & \\
\hline \multirow{3}{*}{$\begin{array}{l}\text { Non-legal } \\
\text { actions }\end{array}$} & \multirow{2}{*}{$\begin{array}{l}\text { 2. Digital } \\
\text { participation }\end{array}$} & $\begin{array}{c}\text { 2a. online petitions } \\
\text { (e-petitions) on various } \\
\text { web-based petition hosts }\end{array}$ & short & easy & no & low ${ }^{2}$ \\
\hline & & $\begin{array}{c}\text { 2b. online petition } \\
\text { (e-petitions) on a } \\
\text { dedicated organization's } \\
\text { website }\end{array}$ & long/medium & easy/average & no & low ${ }^{3}$ \\
\hline & 3. Other actions ${ }^{1}$ & $\begin{array}{l}\text { letter/email-writing } \\
\text { complaints, protests, } \\
\text { rallies, phone calls, } \\
\text { face-to-face lobbying }\end{array}$ & medium/short & average & no/yes & medium \\
\hline
\end{tabular}

${ }^{1}$ Due to a lack of access to reliable information, these actions have been excluded from the overall analysis and only estimates are provided. ${ }^{2,3}$ Effectiveness has been described as low based on the available results, but because this is such a new participation method, its effectiveness can be improved and developed in the future.

\subsection{Legal Actions: Lawsuits}

Over the past 100 years, the majority of actions in the fight against LP have been legal actions in the form of lawsuits.

It can be seen that in recent decades their number has increased significantly due to the possibility of acquiring knowledge about health and ecology by citizens using the Internet and search engines. Bringing a case to court makes sense in countries where there is a law and/or legal regulations regarding light pollution and light nuisance. This is demonstrated by an example from Shanghai, China, in 2004, when a citizen won their lawsuit case on the day that the city's regulations on light pollution were implemented [106].

The scatter diagram below, reported in Figure 9, describes the association between the variables, including a description of the form, direction, and strength of the association, along with the presence of any outliers [107]. It shows a non-linear, positive, strong, relationship between the number of legal actions and time.

Additionally, in this diagram, a two-point moving average trendline was used to graphically display trends in data more clearly. These results show that since the first law case connected to light pollution identified in 1923, there has been a steady increase in actions observed, with a three-fold increase in the number of lawsuits since 1990. The highest identified number of lawsuit cases in one year was 10 in 2010, and then nine in 2015. This may be due to access to new knowledge on light pollution, thanks to the digital information database to which citizens had access, hence the increase in court cases. In turn, a significant drop in court cases has been visible since 2017, and it can be argued that this is due to the increase in online petitions. 


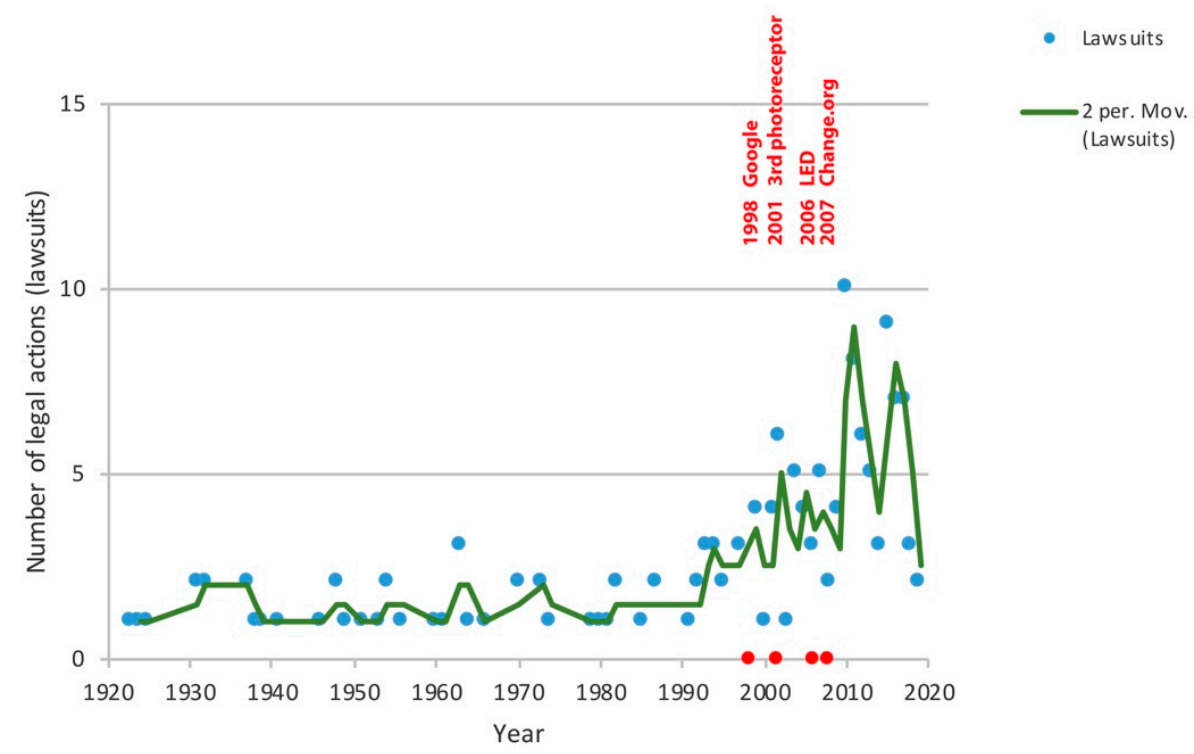

Figure 9. A scatter diagram showing the relationship between the maximum achieved number of legal actions (civil lawsuit cases) over time. Source: Authors' data.

The noticeably high number of legal actions in the US compared to other countries (Figure 10), might be related to the fact that in the US, legal actions are well documented, and detailed information is freely available to the public. Additionally, lighting design as a profession has been established in the USA since the 1970s, and the IDA, which is the world's largest and best-known grassroots organization to combat light pollution, is also based in the US. The authors are aware that language and other factors might be a barrier here, impacting the total number of the lawsuits per country (this has been identified as a limitation in Section 7).

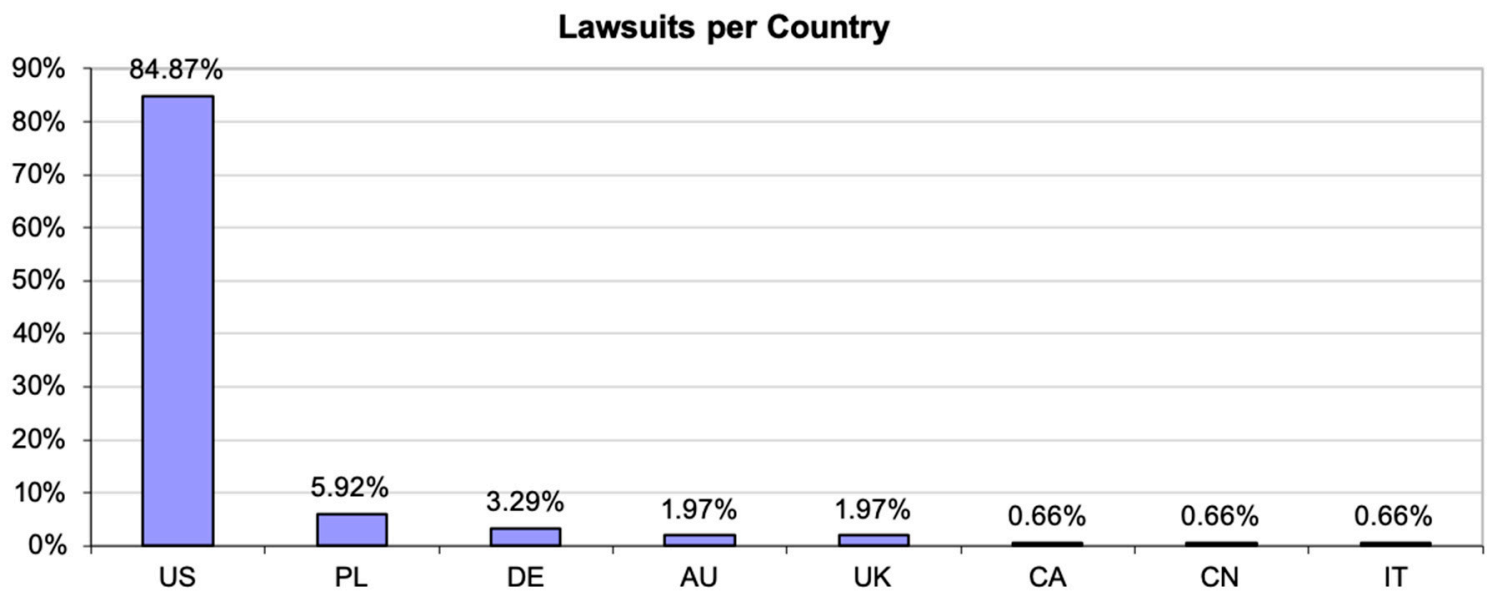

Figure 10. Percentage of lawsuit cases in each country since 1923, presented as a composite bar chart. The two-letter country codes were applied based on the International Standard for country codes ISO-3166 [108]. Source: Authors' data.

Out of the eight identified ALAN nuisance categories of lighting types which can negatively impact human health, well-being, and entire ecosystems, the highest offenders seem to be Building and nonbuilding structure lighting and Sport facility lighting, covering around $25 \%$ of the overall cases, followed by Industrial and commercial lighting with around 16\%, Street and area lighting, then Safety and security lighting both with around 13\%, respectively (Figure 11). Based on information from existing court documents, such high numbers in the first instance are a result of light nuisance in residential neighborhoods, for example, when light directly intrudes into nearby homes which reduces 
the enjoyment of properties, and due to the quiet nature of neighborhoods also results in adverse effects on quality of life. Such disruption can cause sleep deprivation which can result in ill health and negative psychological conditions. Lastly, such ALAN nuisance reduces the value of properties. Park and garden lighting as well as Event lighting both achieve the lowest results of around one percent.

\section{Categories of Lighting Types}

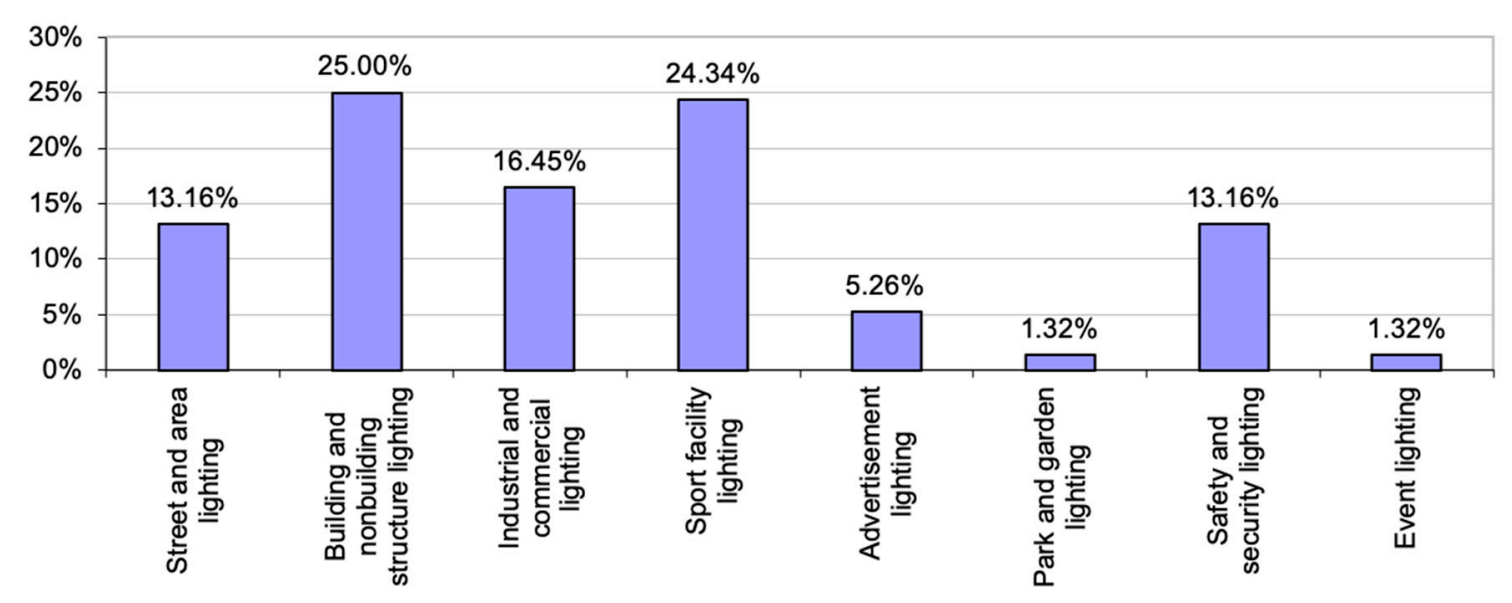

Figure 11. Percentage of lawsuit cases based on eight categories of lighting types, presented as a composite bar chart. Source: Authors' data.

There is also a visible increase in recent years in lawsuits connected to planned projects, of around $38 \%$, compared to existing ones which reach around $61 \%$ (Figure 12).

\section{Projects: Existing / Planned}

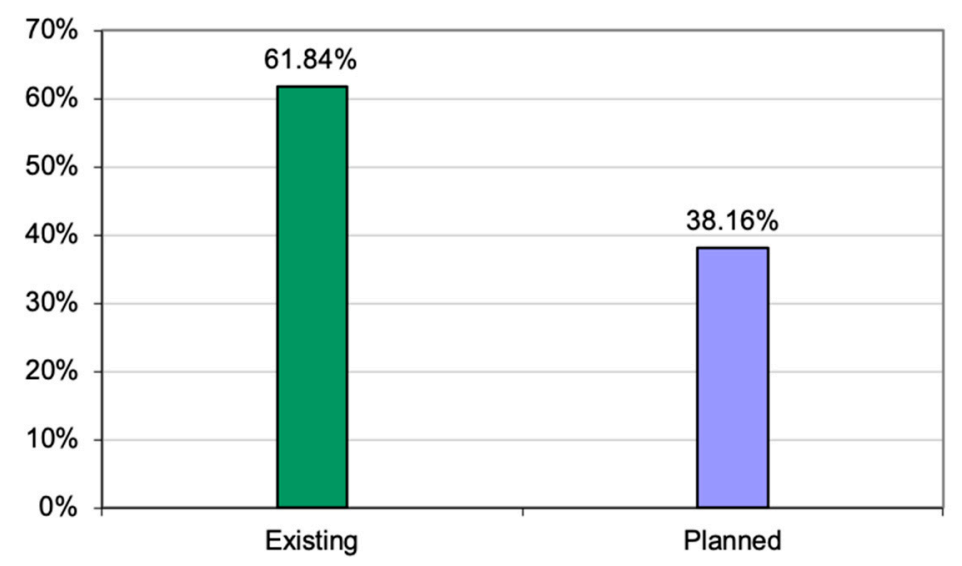

Figure 12. Percentage of lawsuit cases since 1923, based on their status: Existing or planned, presented as a composite bar chart. "Planned" refers to future construction projects which require planning permission. Source: Authors' data.

It is important to emphasize here, the value of collaborating with lighting professionals who can evaluate the claim, present expert testimony, and provide reasonable arguments to submit a lawsuit. Today, these professionals employ tools such as illuminance and luminance meters for existing projects and lighting design software for planned projects (lighting simulations), to estimate with great accuracy the impact of sky glow, light trespass, and/or glare. In the past, plaintiffs did not have sufficient legal standing because they often failed to provide substantial evidence that they would be harmed by the lights from a proposed development. This matters because private nuisance claims require proof of the 
actual injury suffered, not just potential injury from increased light pollution [109] or the potential of significant negative impacts on the environment [110].

While projects require planning permission, if citizens decide to take action and dispute a proposed project because it may harm their health and/or reduce their life quality, matters can be drawn out and take years to resolve.

There has been almost the same number of successful lawsuits (around $48 \%$ ) as there has been documented lost cases (around 51\%) (Figure 13). The final result of a lawsuit may be affected by the lack of proper substantive preparation of documents and a lack of awareness of the legal processes involved by complainants, as it is recorded in existing court papers. Often, in order to save costs, citizens use self-help and non-legal professionals, rather than paying for lawyers. This may affect the quality of submitted paperwork, as well as the final outcome. Other factors that can hinder success are common issues, such as a lack of knowledge of legal procedures. For instance, the complainant misses filing paperwork by the due date, they are unclear when the problem first began, they may claim injuries which are not actionable under common law nuisance, and there may also be confusion over land use, zoning ordinances, as well as city and state codes, etc.

Lawsuits: Success / Failure

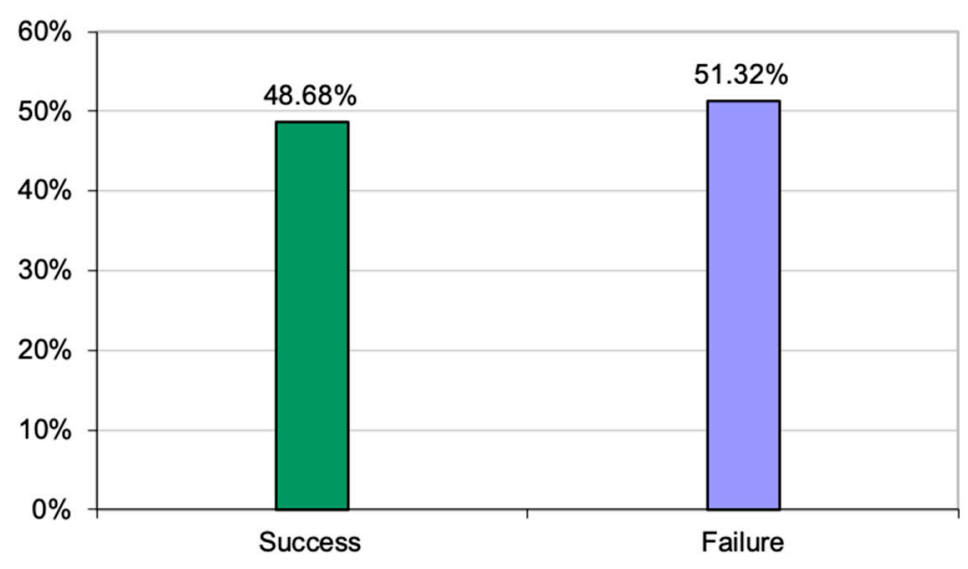

Figure 13. Percentage of lawsuit cases since 1923, based on their status: Success or failure, presented as a composite bar chart. Source: Authors' data.

\subsection{Non-Legal Actions: Digital Participation in Form of Online Petitions}

The non-legal actions, in the form of digital participation, such as online petitions to protect dark skies and the health and well-being of humans from light pollution are relatively new tools that have developed in the last ten years.

The scatterplot diagram reported in Figure 14 shows a linear, positive, strong relationship between the number of online petitions and time. Since the first e-petition connected to light pollution was identified in 2012, there has been a steady increase in actions observed in the last decade, with sharp peaks from around the year 2015 onwards.

The highest identified number of e-petitions in one year was 40, in 2019. Additionally, in this diagram a two-point moving average trendline was used to graphically display trends in data more clearly.

Again, the noticeably high number of online petitions in the US (close to $60 \%$ ) compared to other countries (Figure 15), might be related to the fact that tools such as computer and Internet technologies, including online petition websites, were first developed in the US. Additionally, one could assume that the English language might play a role here, with the higher number of actions undertaken in countries such as the UK, Australia, and Canada, compared to the rest of the world. 


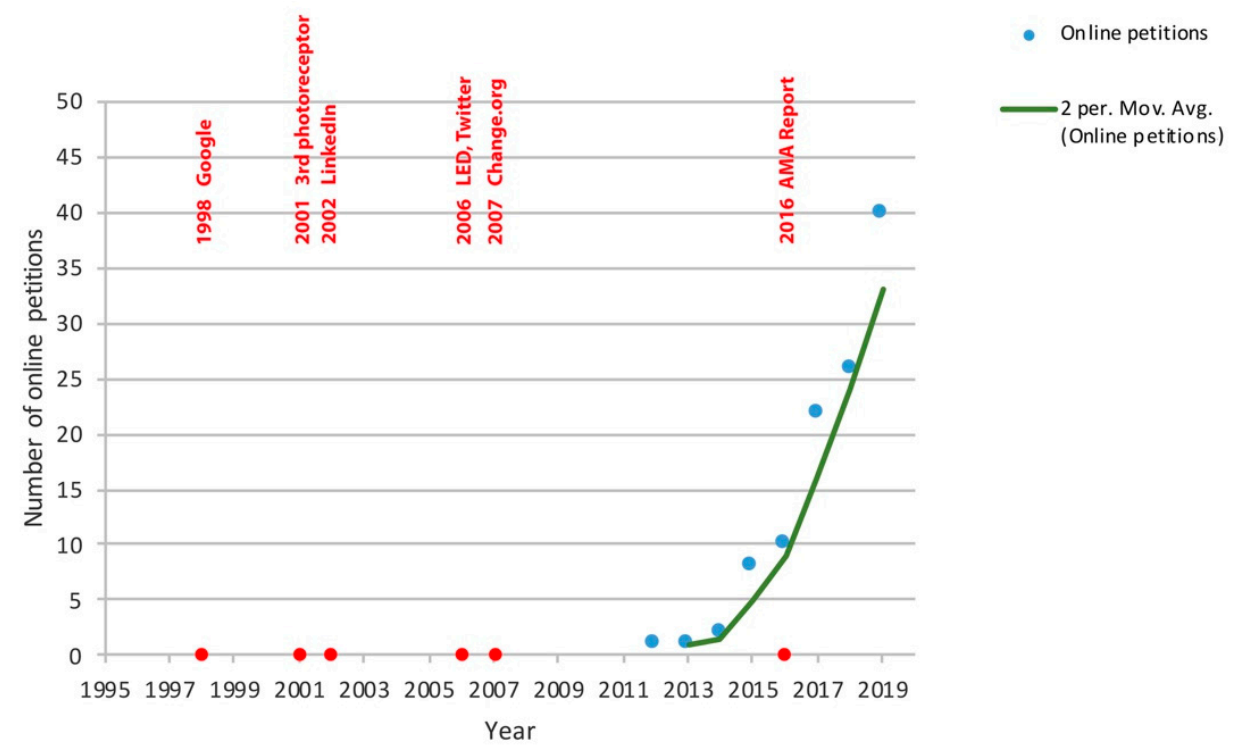

Figure 14. A scatterplot diagram showing the relationship between the maximum achieved number of non-legal actions (online petitions) per year. Source: Authors' data.

Number of e-petitions per Country

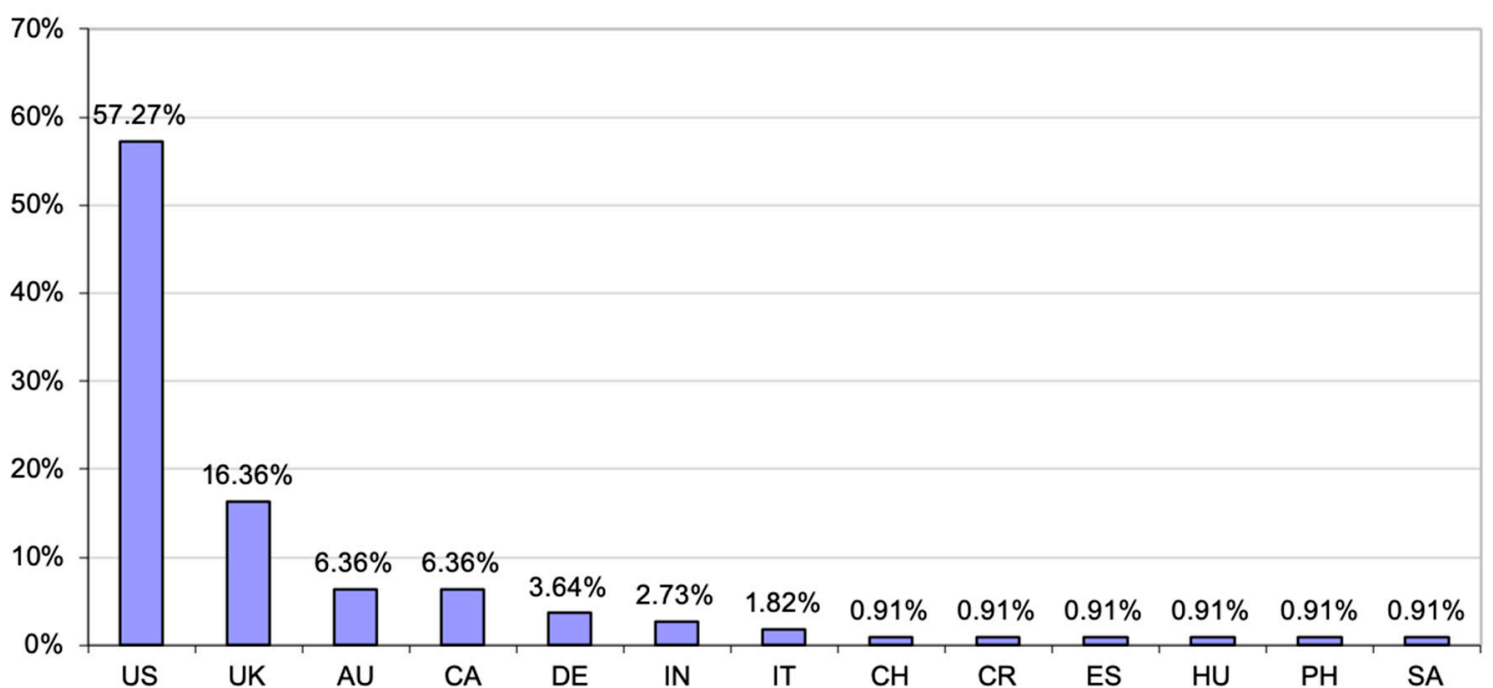

Figure 15. Percentage of e-petitions cases based on their country, presented as a composite bar chart. The two-letter country codes were applied based on the International Standard for country codes ISO-3166 [109]. Source: Authors' data.

It was difficult to assign eight categories of lighting types based on the previous categories (Figure 11) in order to establish the percentage of online petition cases, as new categories such as light pollution legislation proposals, and light pollution projects with a wider environmental impact were identified.

Furthermore, it was not possible from the provided information, to identify the exact number of results (success or failure) of e-petitions, as often this information was unavailable on the website, or the petition was still ongoing.

Moreover, the number of participants who signed the petitions will also vary unproportionable, with the ones that related to environmental topics achieving the highest number of signatures-133,536 [111] and 117,950 [112], respectively, compared to petitions that received zero signatures [113]. On many e-petition websites there are no clear rules regarding the number of signatures required in order to be 
successful. In the UK, for instance, such rules are provided on the government's website. For example, only British citizens and UK residents may create a petition, and if 10,000 signatures are collected, a petitioner will get a response from the government, whereas, if 100,000 signatures are gathered, the petition will be considered for debate in the UK Parliament [114]. Also, some of the local councils in the UK define the minimum number of signatures per e-petition [115]. For example, the petitioner has a right to present his petition to a meeting of members of the council, subject to the number of people who signed the e-petition. For a county council meeting, 1000 signatures are required, for a Cabinet or Cabinet panel meeting, 250 signatures are required. When achieving 100 signatures, there is an opportunity to raise the issue directly with the executive or local member of the council.

\subsection{Comparison of Legal and Non-Legal Actions Against Light Pollution}

Since 2010, there has been a noticeable increase in the number of online petition cases connected to the impact of ALAN and light pollution. Online petitions have achieved almost $65 \%$, which is almost a two-fold increase in the amount of lawsuit cases (Figure 16).

Lawsuits versus e-petitions

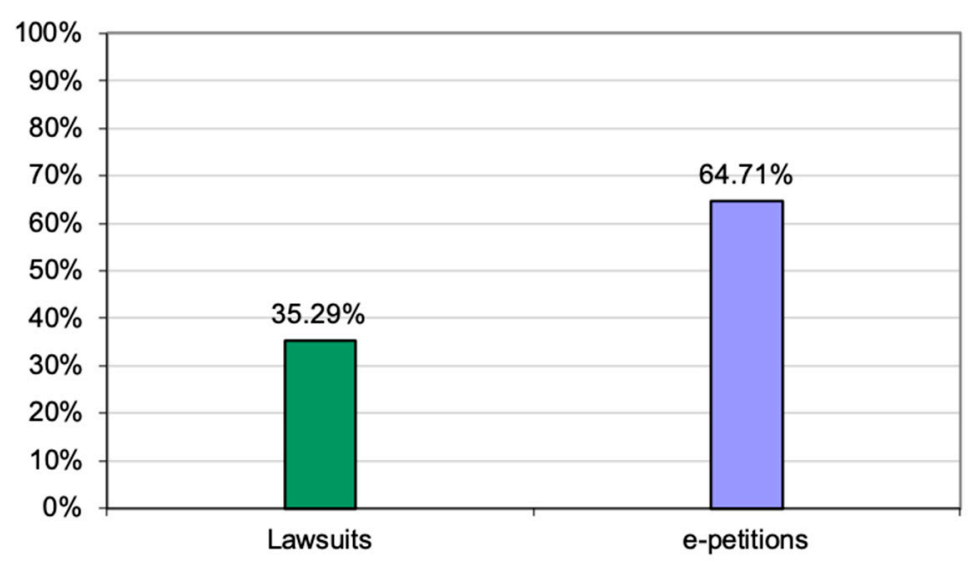

Figure 16. Percentage of lawsuits versus e-petitions cases against light pollution in the last decade, presented as a composite bar chart. Source: Authors' data.

\section{Discussion}

In the presented research study, an evaluation of accounts of legal and non-legal international citizens' actions was carried out with the help of mixed research methods to create robust science-informed data about the various methods citizens undertake to resolve light pollution disputes.

The results, presented in Figure 9, support the hypothesis, and highlight the fact that, since the 1990s, there has been a significant increase in legal actions related to light pollution. This is due to the increase in use of the Internet by citizens, that begun in the 1990s, coupled with the availability of online information via Google search engine (1998) and Wikipedia Commons (2001). The continuous increase in the number of online petitions on a dedicated organization's website (Figure 14) support the hypothesis of a new movement of citizens' actions.

These findings indicate that citizen's awareness about LP is evolving. The rapid global evolution of digital technologies has not only changed the behavior and expectations of people concerned about light pollution, it has also greatly influenced their involvement, activity, and participation with such platforms. Therefore, it seems that existing and developing digital technologies will have a significant impact on the way citizens engage in disputes, and they will also help determine how they achieve positive outcomes.

By analyzing this new option for citizens' participation, one can predict that an online petition might become the most preferred tool in the future for successful citizens' actions due to numerous 
factors. By gathering participants signatures quickly and easily, online petitions can take communication to the next level and reach a much wider audience. Their duration is also much shorter in time and there is no associated cost involved. This form of action seems to be simple and easy to set up (computer and Internet access are required). Online petitions are also accessible at any time and provide a free-of-charge tool to communicate citizens' concerns.

However, the estimated high number of unsuccessful results of online petitions suggests there is a lack of insight about how to create and execute initiatives that achieve positive outcomes. For this reason, if an online petition has been selected as a method to raise awareness and instigate positive change, it is important to consider the following 10 elements as a guide to success, based on the performed analysis (Table 3).

Table 3. Ten aspects to be considered when addressing the nuisance of artificial light at night (ALAN), for a successful online petition result. Source: Authors' elaboration.

\begin{tabular}{|c|c|c|}
\hline No. & Aspect & Description \\
\hline 1 & Platform type & $\begin{array}{l}\text { There are various websites that provide a petition platform and some } \\
\text { of them are well known for achieving political impact. Choosing the } \\
\text { correct one might depend upon the matter to be addressed. Is it a } \\
\text { local or global light pollution issue? } \\
\text { Also, it is recommended to use a petition platform that can perform a } \\
\text { search within the website itself, with various key words such as the } \\
\text { ones mentioned in Section } 4.1 \text {, to see if similar petitions exist. }\end{array}$ \\
\hline 2 & Language chosen & $\begin{array}{l}\text { In some light pollution cases, language may be a barrier [116]. As } \\
\text { English is the most widespread language worldwide, it seems to be } \\
\text { the best for communication (1.5 billion people, approximately } 20 \% \text { of } \\
\text { Earth's population speak English). Make your light pollution petition } \\
\text { international. Some successful petitions have been translated into a } \\
\text { number of different languages [117]. }\end{array}$ \\
\hline 3 & Title & $\begin{array}{l}\text { Your title should be informative and specific as it will provide a clear } \\
\text { statement to the reader, articulating your aim [118]. Make it short, as } \\
\text { this will attract a higher number of viewers and it will be easier to } \\
\text { remember. Use well known words or phrases associated with the } \\
\text { topic of light pollution as they will most likely be recognized by } \\
\text { performed searches. }\end{array}$ \\
\hline 4 & $\begin{array}{l}\text { Recipient(s) of } \\
\text { petition/responsible for } \\
\text { decision making }\end{array}$ & $\begin{array}{l}\text { It is important to directly address the recipient of the petition with } \\
\text { their name, as this will apply pressure for a response [112]. (It will be } \\
\text { less effective for instance, to address your petition to the "President of } \\
\text { the United States" or "Everyone" [119].) } \\
\text { It is also important to check whether those being petitioned are in a } \\
\text { position to make changes related to light pollution issues. }\end{array}$ \\
\hline 5 & $\begin{array}{l}\text { Required number of } \\
\text { supporters }\end{array}$ & $\begin{array}{l}\text { It is widely believed the success of a light pollution petition depends } \\
\text { on how many signatures are gathered, however, this is relative, as } \\
\text { what really matters is the issue's status-is it local, regional, or global? } \\
\text { Sometimes, limited votes can be enough to instigate a change to } \\
\text { reduce light pollution by a local council [120]. A general rule should } \\
\text { be the more supporters' signatures collected, the better. }\end{array}$ \\
\hline 6 & $\begin{array}{l}\text { Defining your } \\
\text { audience/supporters }\end{array}$ & $\begin{array}{l}\text { If the audience is chosen casually and the campaign unsupported by } \\
\text { active engagement, initiatives against light pollution can receive } \\
\text { fewer supporters, and result in a failed outcome [121]. }\end{array}$ \\
\hline
\end{tabular}


Table 3. Cont.

\begin{tabular}{|c|c|c|}
\hline No. & Aspect & Description \\
\hline 7 & Message content & $\begin{array}{l}\text { Break down complex matter. Use simple language that is easy to } \\
\text { understand, with links to references, reports, and testimonials, etc., on } \\
\text { light pollution issues. } \\
\text { Your text needs to be concise and succinct, between } 150-650 \text { words. } \\
\text { Create engaging content, and clearly answer the following two } \\
\text { questions: (1) Why are you petitioning? (2) What impact do you hope } \\
\text { to achieve through this action against light pollution? A well } \\
\text { prepared and determined approach will be taken more seriously from } \\
\text { the start. To be seen and heard in today's world of information } \\
\text { overload, potential signatories are more likely to support your light } \\
\text { pollution petition when they understand its aim and purpose. Keep it } \\
\text { personal and authentic. Your supporters will endorse an initiative } \\
\text { they can intellectually and emotionally connect with and want to be } \\
\text { involved in to make a positive difference. If people do not support } \\
\text { your petition, perhaps the message was not communicated in the } \\
\text { right way or the topic appeared to be unimportant. It is advisable to } \\
\text { engage and consult with researchers, advocates, etc. Always sign } \\
\text { your petition on behalf of interest groups, communities, associations, } \\
\text { etc., as this can add more credibility and weight to the goal and } \\
\text { convince those people who are undecided. }\end{array}$ \\
\hline 8 & $\begin{array}{l}\text { Provide additional } \\
\text { eye-catching material in } \\
\text { order to stand out }\end{array}$ & $\begin{array}{l}\text { As humans absorb more than } 80 \% \text { of information visually, } \\
\text { eye-catching information about light pollution can help explain your } \\
\text { subject in a convincing and engaging way [122]. Video can capture } \\
\text { and communicate a message to potential signatories in a way that } \\
\text { other mediums cannot [123]. }\end{array}$ \\
\hline 9 & $\begin{array}{l}\text { Spreading the } \\
\text { message/attracting your } \\
\text { supporters }\end{array}$ & $\begin{array}{l}\text { Prepare fact sheets and other free material on light pollution and } \\
\text { share it at live events to engage with people. Use social media such as } \\
\text { Twitter, Facebook, and Instagram, but also send out personal emails to } \\
\text { attract more supporters. Write journal articles, create press releases, } \\
\text { and connect with journalists and radio presenters to report your light } \\
\text { pollution case and share your story [124,125]. }\end{array}$ \\
\hline 10 & $\begin{array}{c}\text { Delivering your petition } \\
\text { and providing feedback } \\
\text { to supporters }\end{array}$ & $\begin{array}{l}\text { It is advisable to arrange a personal meeting to hand over your light } \\
\text { pollution petition, and if this is not possible, write a personal letter } \\
\text { that includes all signatures. Always update your supporters on the } \\
\text { status of your light pollution initiative with short text, pictures, and/or } \\
\text { links [126]. }\end{array}$ \\
\hline
\end{tabular}

In order to empower citizens, it is of utmost importance to allow them to exercise their rights, and to enable them to make informed decisions via easy access to quality, reliable, up-to-date information. Thus, the authors propose the creation of a data repository, in the form of a website platform called Light Pollution Case Study Actions Database (LPCSA), to assemble worldwide data that goes beyond the presented case studies on the subject, which could perform similarly to the Artificial Light At Night Research Literature Database on the IDA website [127]. It is expected that this format will provide a basic structure for such research information and provide a starting point which can be expanded to reflect the findings, and offer new insights and creative approaches for contextualizing this problem. Additionally, creating a single online petition website explicitly related to light pollution issues might be very helpful to improve citizens' actions. Whether such initiatives and research could be embraced should be verified in the future with the IDA and other organizations. Knowledge dissemination of successful non-legal actions to decrease light pollution, via news media coverage and other forms, should be one of the top priorities of activists, as some people might still lack awareness that the negative aspects of ALAN can be resolved through citizens taking action. 


\section{Limitations of the Study}

Aside from the contributions stated in Section 6, this enquiry also has its limitations which are acknowledged below:

- The availability of accessible data might be an issue (inaccurate or limited), as not all citizen actions could be found by online searches and/or have been reported by media channels.

- Language can sometimes be a communication barrier. Due to the broad scope of the research, it is highly likely there are lawsuits and online petitions recorded and reported in languages other than English, German, and Polish, which have not been included in this study, therefore, the sample size might not be representative worldwide.

- The number of subject-related keywords used by authors when searching through online petition websites may be restrictive which would prevent all of the cases being found.

- Although information is reliable for legal actions such as lawsuits in the US and UK, in other countries, such information (the exact city where the process has taken place, the name of a defendant, etc.) might be difficult for the public to access due to legal reasons and confidentiality.

- There is often no feedback on the status of an online petition. This might mean that the petition is still ongoing, was unsuccessful, or the petition organizer lost interest in the petition.

- Some legal actions are still unresolved; therefore, these could not be included in the final outcome analysis related to their success or failure.

- The outcomes of analyzed data in the future might be out of date, due to the rapid changes involving the day-to-day sharing of new information.

\section{Conclusions}

In the presented study, information pertaining to active participation by citizens, and practices related to light pollution and their impact, have been collected and analyzed. The research offers significant evidence that there is a global need for effective, non-legal mitigation strategies to address light pollution, which require immediate attention and improvement. It also makes a novel contribution to literature, as to our knowledge, this is the first time such a wide spectrum investigation (not only lawsuits, but also online petitions) has been analyzed on this subject. Moreover, our study also reveals that while public awareness has risen in recent years and numerous actions have taken place, only a few non-legal cases have been successful. These have related mainly to environmental actions and animal welfare. It seems that if the public's approach is well thought through, carefully planned, and fully coordinated, a successful outcome is much more likely to occur.

As there are no well-known guidelines for citizens' actions related to the reduction of the impact of light pollution, a seven-step framework (Table 4) has been developed to provide important insights for the management of the process, which can be adopted by any interested party wanting to take action.

Table 4. A practical seven-step process involving guidelines for citizens' actions to reduce light pollution and its impact. Source: Authors' elaboration.

\begin{tabular}{|c|c|c|}
\hline Step & Category & Description \\
\hline Step 1 & Identify the issue & $\begin{array}{l}\text { Identify the nuisance/source of disturbance created by } \\
\text { artificial lighting at night, by answering the following } \\
\text { questions: Is it a hazard to safety? Would it produce } \\
\text { ecological disturbance of any sort? Can it cause } \\
\text { environmental and visual nuisance? Is energy waste } \\
\text { visible to the naked eye? }\end{array}$ \\
\hline Step 2 & Check the regulations & $\begin{array}{l}\text { Check the allowed lighting requirements/limits based } \\
\text { on environmental zones (permitted level of sky glow, } \\
\text { light intrusion into windows, or building luminance) in } \\
\text { the area where the obtrusive light issue occurs. }\end{array}$ \\
\hline
\end{tabular}


Table 4. Cont.

\begin{tabular}{|c|c|c|}
\hline Step & Category & Description \\
\hline Step 3 & $\begin{array}{l}\text { Collect the evidence (document } \\
\text { and assess the issue) }\end{array}$ & $\begin{array}{l}\text { Take photographs and videos to thoroughly document } \\
\text { the issue, keep a diary of observations that record light } \\
\text { pollution characteristic with details that include dates } \\
\text { and times. If possible, also perform measurements to } \\
\text { compare the outcome with the limits allowed in } \\
\text { standards and guidelines. }\end{array}$ \\
\hline Step 4 & Join forces with others & $\begin{array}{l}\text { Network with your neighbors and connect with other } \\
\text { citizens interested in supporting your actions; be part of } \\
\text { a larger group that is involved in similar struggles. Talk } \\
\text { to people who might have been through a similar } \\
\text { experience to learn from their attempts (mistakes and } \\
\text { successes). Educate the public on the presence of light } \\
\text { pollution in their community. Seek support from } \\
\text { policy makers. }\end{array}$ \\
\hline Step 5 & $\begin{array}{l}\text { Consult experts } \\
\text { to reinforce your views }\end{array}$ & $\begin{array}{l}\text { Consult with authorities on the issue (light pollution } \\
\text { experts such as environmentalists, } \\
\text { photobiologists/chronobiologists, lighting designers, } \\
\text { astronomers, members of local scientific societies, } \\
\text { conservation groups, or environmental associations, } \\
\text { and others). Your issue should be supported by facts, } \\
\text { references, and/or expertise. }\end{array}$ \\
\hline Step 6 & Take action & $\begin{array}{l}\text { Decide on the most appropriate non-legal action to be } \\
\text { taken to resolve the issue (see Table } 2 \text { ). When all options } \\
\text { of negotiations have been tried, consult an } \\
\text { environmental lawyer if necessary. }\end{array}$ \\
\hline Step 7 & Be persistent & $\begin{array}{l}\text { A successful outcome might take a few years, therefore, } \\
\text { it is important to be patient, consistent with the pressure } \\
\text { applied to decision makers, and persistent in your } \\
\text { efforts for a favorable resolution. }\end{array}$ \\
\hline
\end{tabular}

Additionally, it is important to highlight the need for collaboration with lighting professionals in this process, as they are knowledgeable about many aspects of artificial lighting. This means solid technical, design, and implementation knowledge can be provided, and any complaints can be professionally evaluated. Also, support arguments for necessary change and improvement can be offered, as some lighting professionals work on a pro bono basis [128,129]. To boot, members of many organizations (see Section 2.4) can provide advice and guidance on negative outdoor lighting practices and the relevant policies needed to mitigate these issues.

It is also strongly recommended that, in the future, before any new construction or refurbishment activity connected to outdoor lighting is planned in residential or natural environments, an Environmental Impact Report (EIR) is conducted by experts for various authorities (central government, the province, or the municipality) to evaluate possible environmental and health effects. Citizens can approach their local municipal authorities with their concerns and pressure these decisionmakers to take the issues further, to instigate positive change with local government. This can help to establish anti-light pollution policies that will enable towns and cities to install ecologically/biologically responsible lighting.

Finally, it is expected that this work will likely solicit debate and extend discussion on the development of specific light pollution mitigation strategies on global/international, national, and regional levels. It may also assist in the necessary improvement of upcoming anti-light pollution related legislations and regulations by policy and planning officers, introducing technical lighting parameters, and zoning and curfew times as a frame of reference. Such provisions will give active 
citizens the necessary tools to be well equipped to challenge, and in some cases prevent, the adverse effects of light pollution from ALAN.

Author Contributions: Conceptualization, K.M.Z.-D.; methodology, K.M.Z.-D.; software, K.M.Z.-D.; validation, K.M.Z.-D., formal analysis, K.M.Z.-D.; investigation, K.M.Z.-D.; resources, K.M.Z.-D.; data curation, K.M.Z.-D. K.X., and K.B.; writing-original draft preparation, K.M.Z.-D.; writing—review and editing, K.M.Z.-D., K.X., and K.B.; visualization, K.M.Z.-D.; funding acquisition, K.M.Z.-D. All authors have read and agreed to the published version of the manuscript.

Funding: This research received no external funding, except the fee covered from the GUT for an online gold open access publication.

Acknowledgments: The authors would like to thank the anonymous reviewers of this paper for their valuable comments. Additionally, the authors would like to thank Catherina Perez Vega for her contribution with graphical content for Figure 2.

Conflicts of Interest: The authors declare no conflict of interest.

\section{References}

1. Kyba, C.C.M.; Kuester, T.; De Miguel, A.S.; Baugh, K.; Jechow, A.; Hölker, F.; Bennie, J.; Elvidge, C.D.; Gaston, K.J.; Guanter, L. Artificially lit surface of Earth at night increasing in radiance and extent. Sci. Adv. 2017, 3, e1701528. [CrossRef] [PubMed]

2. Riegel, K.W. Light Pollution: Outdoor lighting is a growing threat to astronomy. Science 1973, 179, $1285-1291$. [CrossRef] [PubMed]

3. Gaston, K.J.; Visser, M.E.; Hölker, F. The biological impacts of artificial light at night: The research challenge. Philos. Trans. R. Soc. Lond. B Boil. Sci. 2015, 370, 20140133. [CrossRef] [PubMed]

4. Black Marble: Amazing Earth at Night Photos from Space. Available online: https://www.space.com/19049black-marble-earth-night-photos.html (accessed on 26 May 2020).

5. Gallaway, T. On Light Pollution, Passive Pleasures, and the Instrumental Value of Beauty. J. Econ. Issues 2010, 44, 71-88. [CrossRef]

6. Narisada, K.; Schreuder, D. Light pollution and astronomy. In Galactic Bulges; Springer: Dordrecht, NL, USA, 2004; Volume 322, pp. 115-138.

7. Stone, T. The Value of Darkness: A Moral Framework for Urban Nighttime Lighting. Sci. Eng. Ethics 2017, 24, 607-628. [CrossRef]

8. Bobkowska, K.; Janowski, A.; Jasinska, K.; Kowal, P.; Przyborski, M. Light pollution in the context of threats to the wildlife corridors. In Proceedings of the 16th International Multidisciplinary Scientific GeoConference SGEM2016, Vienna, Austria, 2-5 November 2016; STEF92 Technology: Sofia, Bulgaria, 2016; pp. 665-670.

9. Liu, M.; Zhang, B.; Li, W.; Guo, X.; Pan, X. Measurement and distribution of urban light pollution as day changes to night. Light. Res. Technol. 2017, 50, 616-630. [CrossRef]

10. Gallaway, T.; Olsen, R.; Mitchell, D.M. The economics of global light pollution. Ecol. Econ. 2010, 69, 658-665. [CrossRef]

11. Morgan-Taylor, M. Regulating light pollution in Europe: Legal challenges and ways forward. In Urban Lighting, Light Pollution and Society; Meier, J., Hasenoehrl, U., Krause, K., Pottharst, M., Eds.; Taylor \& Francis: New York, NY, USA, 2014; pp. 159-176.

12. Hölker, F.; Moss, T.; Griefahn, B.; Kloas, W.; Voigt, C.C.; Henckel, D.; Hänel, A.; Kappeler, P.M.; Völker, S.; Schwope, A.; et al. The Dark Side of Light: A Transdisciplinary Research Agenda for Light Pollution Policy. Ecol. Soc. 2010, 15. [CrossRef]

13. Spivey, A. LIGHT POLLUTION: Light at Night and Breast Cancer Risk Worldwide. Environ. Health Perspect. 2010, 118, A525. [CrossRef]

14. Zubidat, A.E.; Haim, A. Artificial light-at-night-A novel lifestyle risk factor for metabolic disorder and cancer morbidity. J. Basic Clin. Physiol. Pharmacol. 2017, 28, 295-313. [CrossRef]

15. Ściężor, T. Light pollution as an environmental hazard. Tech. Trans. 2019, 8, 129-142. [CrossRef] 
16. Zielinska-Dabkowska, K.M. Critical Perspectives on Media Architecture: Is it Still Possible to Design Projects without Negatively Attracting Urban Nighttime Environments and Will the Future Remain Dynamic, Bright and Multi-Colored? In Proceedings of the 2nd ACM Conference Media Architecture Biennale (MAB 2014), Aarhus, Denmark, 19-22 November 2014; The Association for Computing Machinery (ACM): New York, NY, USA, 2014; pp. 101-108. [CrossRef]

17. Zielinska-Dabkowska, K.M. Urban Lighting Masterplan—Definitions, Methodologies and Collaboration. In Urban Lighting for People: Evidence-Based Lighting Design for the Built Environment, 1st ed.; Davoudian, N., Ed.; RIBA Publishing: London, UK, 2019; pp. 18-41, ISBN 9781859468210.

18. Papalambrou, A.; Doulos, L.T. Identifying, Examining, and Planning Areas Protected from Light Pollution. The Case Study of Planning the First National Dark Sky Park in Greece. Sustainability 2019, 11, 5963. [CrossRef]

19. Meier, J. Contentious Light: An Analytical Framework for Lighting Conflicts. Int. J. Sustain. Light. 2019, 20, 62-77. [CrossRef]

20. Johnson, A.L. Blinded by the Light: Addressing the Growing Light Pollution Problem. Tex. A M J. Prop. Law 2015, 2, 461-480.

21. Beyond Rods and Cones. Available online: https://www.brown.edu/Administration/News_Bureau/2001-02/ 01-080.html (accessed on 26 May 2020).

22. Zielinska-Dabkowska, K.M.; Xavia, K. Protect our right to light. Nature 2019, 568, 451-453. [CrossRef]

23. Zielinska-Dabkowska, K.M. Make lighting healthier. Nature 2018, 553, 274-276. [CrossRef]

24. Our Nights are Getting Brighter, and Earth Is Paying the Price. Available online: https://www.nationalgeographic. com/science/2019/04/nights-are-getting-brighter-earth-paying-the-price-light-pollution-dark-skies/ (accessed on 26 May 2020).

25. Supronowicz, R.; Fryc, I. Urban park lighting as a source of botanical light pollution. Phot. Lett. Pol. 2019, 11, 90-92. [CrossRef]

26. Jakubowski, P. Artificial light sources as light pollutant of humans melatonin suppression. Phot. Lett. Pol. 2019, 11, 78-80. [CrossRef]

27. Grubisic, M.; Haim, A.; Bhusal, P.; Dominoni, D.M.; Gabriel, K.M.A.; Jechow, A.; Kupprat, F.; Lerner, A.; Marchant, P.; Riley, W.; et al. Light Pollution, Circadian Photoreception, and Melatonin in Vertebrates. Sustainability 2019, 11, 6400. [CrossRef]

28. American Medical Association [AMA]. CSAPH Report 2-A-16. Available online: https://www.darksky.org/ wp-content/uploads/bsk-pdf-manager/AMA_Report_2016_60.pdf (accessed on 26 May 2020).

29. Response to the 2016 AMA Report on LED Lighting. Available online: https://www.lrc.rpi.edu/resources/ newsroom/AMA.pdf (accessed on 26 May 2020).

30. Response to AMA report on Outdoor Lighting. Available online: https://www.ies.org/about-outreach/policybriefsdocuments/response-to-ama-report-on-outdoor-lighting/ (accessed on 26 May 2020).

31. NEMA Responds to AMA: "A single solution is simply not appropriate for all situations". Available online: https://edisonreport.com/nema-responds-to-ama-a-single-solution-is-simply-not-appropriate-forall-situations/ (accessed on 26 May 2020).

32. Some Cities are Taking another Look at LED Lighting after AMA Warning. Available online: https://www.washingtonpost.com/national/health-science/some-cities-are-taking-another-look-at-ledlighting-after-ama-warning/2016/09/21/98779568-7c3d-11e6-bd86-b7bbd53d2b5d_story.html (accessed on 26 May 2020).

33. The Truth about Blue Light: Does it Really Cause Insomnia and Increased Risk of Cancer? Available online: https://www.theguardian.com/lifeandstyle/2018/may/28/blue-light-led-screens-cancer-insomniahealth-issues (accessed on 26 May 2020).

34. New LED Streetlights may Double Cancer Risk, New Research Warns. Available online: https://www. telegraph.co.uk/science/2018/04/26/new-led-streetlights-may-double-cancer-risk-new-research-warns/ (accessed on 26 May 2020).

35. Baum, H.S. Citizens Participation. Int. Encycl. Soc. Behav. Sci. 2001, 1840-1846.

36. Light Pollution. Available online: https://www.britannica.com/science/light-pollution (accessed on 26 May 2020). 
37. Zielinska-Dabkowska, K.M.; Xavia, K. Global Approaches to Reduce Light Pollution from Media Architecture and Non-Static, Self-Luminous LED Displays for Mixed-Use Urban Developments. Sustainability 2019, 11, 3446. [CrossRef]

38. Man-Made Sky Glow. Available online: http://eilv.cie.co.at/term/755 (accessed on 12 June 2020).

39. The Harmful Northern Lights of Agriculture. Available online: https://www.liberation.fr/france/2019/06/02/ les-nocives-aurores-boreales-de-1-agriculture_1730627 (accessed on 26 May 2020).

40. Berge, J.; Geoffroy, M.; Daase, M.; Cottier, F.; Priou, P.; Cohen, J.H.; Johnsen, G.; McKee, D.; Kostakis, I.; Renaud, P.E.; et al. Artificial light during the polar night disrupts Arctic fish and zooplankton behaviour down to $200 \mathrm{~m}$ depth. Commun. Boil. 2020, 3, 102-108. [CrossRef] [PubMed]

41. Adams, C.A.; Blumenthal, A.; Fernández-Juricic, E.; Bayne, E.; Clair, C.C.S. Effect of anthropogenic light on bird movement, habitat selection, and distribution: A systematic map protocol. Environ. Évid. 2019, 8, 13. [CrossRef]

42. Zielinska-Dabkowska, K.; Xavia, K. Historic Urban Settings, LED Illumination and its Impact on Nighttime Perception, Visual Appearance, and Cultural Heritage Identity. In Proceedings of the 5th SGEM International Multidisciplinary Scientific Conferences on Social Sciences and Arts SGEM2018, Florence, Italy, 23-26 October 2018; STEF92 Technology: Sofia, Bulgaria, 2008; pp. 277-292. [CrossRef]

43. Cabrera-Cruz, S.A.; Smolinsky, J.A.; Buler, J.J. Light pollution is greatest within migration passage areas for nocturnally-migrating birds around the world. Sci. Rep. 2018, 8, 3261. [CrossRef]

44. Zielinska-Dabkowska, K.M. To light or not to light. Exterior illumination of tall buildings and bridges and its negative impact on the life of birds and fish-What professional lighting designers need to know. Prof. Lighting Des. Mag. 2013, 31, 38-43.

45. Škvareninová, J.; Tuhárska, M.; Škvarenina, J.; Babálová, D.; Slobodníková, L.; Slobodník, B.; Středová, H.; Mind'áš, J. Effects of light pollution on tree phenology in the urban environment. Morav. Geogr. Rep. 2017, 25, 282-290. [CrossRef]

46. Dark Skies. Available online: https://www.cpre.org.uk/what-we-care-about/nature-and-landscapes/darkskies/ (accessed on 26 May 2020).

47. About NELPAG. Available online: http://nelpag.org/welcome-and-be-patient/about-nelpag/ (accessed on 26 May 2020).

48. Who We Are. Available online: https://www.darksky.org/about/ (accessed on 26 May 2020).

49. Joining Forces to Protect the Night from Light Pollution. Available online: https://www.darksky.org/joiningforces-to-protect-the-night-from-light-pollution/ (accessed on 26 May 2020).

50. The Commission for Dark Skies. Available online: https://britastro.org/dark-skies/ (accessed on 12 June 2020).

51. Light-Pollution Abatement. Available online: https://www.rasc.ca/lpa (accessed on 26 May 2020).

52. Dark Sky around the World. Available online: https://cielobuio.org/ (accessed on 26 May 2020).

53. The National Association for the Protection of the Night Sky and Environment (ANPCEN). Available online: https://www.anpcen.fr/ (accessed on 26 May 2020).

54. Dark Skies and Nature Conservation. Available online: http://darkskyparks.org/dark-skies-and-natureconservation/ (accessed on 26 May 2020).

55. Who We Are. Available online: https://www.australasiandarkskyalliance.org/ (accessed on 26 May 2020).

56. LPA Special Issue. Available online: https://www.rasc.ca/lpa-special-issue (accessed on 26 May 2020).

57. FLAP Canada's BirdSafe Building Standard. Available online: https://flap.org/wp-content/uploads/2019/11/ FLAP-Canada-BirdSafe-Building-Standard.pdf (accessed on 26 May 2020).

58. International Dark Sky Places. Available online: https://www.darksky.org/our-work/conservation/idsp/ (accessed on 26 May 2020).

59. International Dark-Sky Association. Available online: https://idsw.darksky.org/ (accessed on 26 May 2020).

60. NightBlight Reclaiming Our Dark Skies. Available online: https://www.nightblight.cpre.org.uk (accessed on 26 May 2020).

61. Night Blight: Mapping England's Light Pollution and Dark Skies. Available online: https://www. cpreherefordshire.org.uk/assets/Documents/Reports-and-Leaflets/edd1f203a4/CPRE-Night-Blight-report.pdf (accessed on 26 May 2020).

62. Horton, K.G.; Nilsson, C.; Van Doren, B.M.; A La Sorte, F.; Dokter, A.M.; Farnsworth, A. Bright lights in the big cities: Migratory birds' exposure to artificial light. Front. Ecol. Environ. 2019, 17, 209-214. [CrossRef] 
63. Light Out Programs in North America. Available online: https://www.google.com/maps/d/u/0/ viewer?client=firefox-a\&ie=UTF8\&oe=UTF8\&msa=0\&mid=1KK1G8q-uz9Ix9aKRwqNpbPv1J4A\&ll=38. 08194400040676\%2C-96.8772931748963\&z=4 (accessed on 26 May 2020).

64. Our Mission. Available online: https://www.earthhour.org/our-mission (accessed on 26 May 2020).

65. Jechow, A. Observing the Impact of WWF Earth Hour on Urban Light Pollution: A Case Study in Berlin 2018 Using Differential Photometry. Sustainability 2019, 11, 750. [CrossRef]

66. The Results of Our 2020 Star Count Are in. What Do They Tell Us? Available online: https://www.cpre.org. uk/news/star-count-2020-the-results/ (accessed on 26 May 2020).

67. Star Towns and Villages: A National Label Organized by the ANPCEN. Available online: https://www. anpcen.fr/?id_rub=19 (accessed on 26 May 2020).

68. International Day of Light. Available online: https://www.lightday.org (accessed on 26 May 2020).

69. Proclamation of an International Day of Light. Available online: https://unesdoc.unesco.org/ark:/48223/ pf0000258963 (accessed on 26 May 2020).

70. Stars4ALL. European project to disseminate and research about the problem of light pollution. Available online: https://www.stars4all.eu/ (accessed on 26 May 2020).

71. International Dark-Sky Association. Criteria for Community Friendly Outdoor Sports Lighting v1.0. Available online: https:/www.darksky.org/wp-content/uploads/2018/03/IDA-Criteria-for-CommunityFriendly-Outdoor-Sports-Lighting.pdf (accessed on 26 May 2020).

72. International Dark-Sky Association. Guidance for Electronic Message Centres (EMCs). Available online: https://www.darksky.org/wp-content/uploads/2019/05/EMC-Guidelines-IDA2019-1.pdf (accessed on 26 May 2020).

73. Blinded by the Light? Available online: https://britastro.org/dark-skies/pdfs/CfDS_booklet_Rev07.pdf (accessed on 26 May 2020).

74. Who We Are. Available online: https://www.cen.eu/about/Pages/default.aspx (accessed on 26 May 2020).

75. European Committee for Standardization. EN 12464-2:2014 Light and Lighting-Lighting of Work Places, Part 2: Outdoor Work Places; CEN Publication: Brussels, Belgium, 2014; Available online: https://standards.cen.eu/ dyn/www/f?p=204:110:0::::FSP_PROJECT:39863\&cs=1E581E9018568D61E75F6164A86E44682 (accessed on 26 May 2020).

76. International Commission on Illumination. Guide on the Limitation of the Effects of Obtrusive Light from Outdoor Lighting Installations, 2nd ed.; Technical Report CIE 150; International Commission on Illumination: Vienna, Austria, 2017; ISBN 978-3-902842-48-0.

77. International Commission on Illumination. Guidelines on Minimizing Sky Glow, 1st ed.; Technical Report CIE 126; International Commission on Illumination: Vienna, Austria, 2003; ISBN 978-3-900734-83-1. Available online: http://cie.co.at/publications/guidelines-minimizing-sky-glow (accessed on 26 May 2020).

78. About the IES. Available online: https://www.ies.org/about/ (accessed on 26 May 2020).

79. IDA and IES Model Lighting Ordinance (MLO) with User's Guide. Available online: https://www.darksky. org/our-work/lighting/public-policy/mlo/ (accessed on 26 May 2020).

80. What Does BUG Rating Mean? Available online: https://www.accessfixtures.com/what-is-bug-rating-andwhy-does-it-matter/ (accessed on 26 May 2020).

81. Illuminating Engineering Society. Lighting for Exterior Environments. IES RP-33-14, 1st ed.; IES Publication: New York, NY, USA, 2014; ISBN 978-0-87995-301-0. Available online: https://www.ies.org/product/lightingfor-exterior-environments/ (accessed on 26 May 2020).

82. About. Available online: https://theilp.org.uk/about/ (accessed on 26 May 2020).

83. Institution of Lighting Professionals (ILP). Guidance Note 1 for the Reduction of Obtrusive Light. Guidance Note 01/20; ILP Publication: Rugby, UK, 2020; Available online: https:/theilp.org.uk/publication/guidance-note-1for-the-reduction-of-obtrusive-light-2020/ (accessed on 26 May 2020).

84. Institution of Lighting Professionals (ILP). The Brightness of Illuminated Advertisements. PLG05, 1st ed.; ILP Publication: Rugby, UK, 2013; Available online: https://theilp.org.uk/publication/plg05-the-brightness-ofilluminated-advertisements/ (accessed on 26 May 2020).

85. The Shelburne, Inc. v. Crossan Corp. Available online: https://casetext.com/case/the-shelburne-inc-vcrossan-corp? (accessed on 26 May 2020).

86. Hansen v. Independent S. Dist. No. 1. Available online: https://casetext.com/case/hansen-v-independent-sdist-no (accessed on 26 May 2020). 
87. Weber v. Mann. Available online: https://casetext.com/case/weber-v-mann (accessed on 26 May 2020).

88. Amphitheaters, Inc. v. Portland Meadows-184 Or. 336, 198 P.2d 847. 1948. Available online: https://www.lexisnexis.com/community/casebrief/p/casebrief-amphitheaters-inc-v-portland-meadows (accessed on 26 May 2020).

89. Urban Wildlands Group v. City of Los Angeles. Available online: https://ceqaportal.org/ceqacase.cfm?cq_ $\mathrm{id}=1853$ (accessed on 26 May 2020).

90. Using the California Environmental Quality Act (CEQA) to Turn Out the Lights. Available online: https://californiapolicycenter.org/using-the-california-environmental-quality-act-ceqa-to-turn-outthe-lights/ (accessed on 26 May 2020).

91. Narisada, K.; Schreuder, D. Adverse effects of light pollution. In Light Pollution Handbook; Springer: Dordrecht, NL, USA, 2004; Volume 322, pp. 106-107.

92. United Nations. E-Government Survey 2014 E-Government for the Future We Want; UN Publication: New York, NY, USA, 2014; p. 61. Available online: https://www.un.org/en/development/desa/publications/egovernment-survey-2014.html (accessed on 26 May 2020).

93. Reduce Light Pollution. Available online: https://www.change.org/p/reduce-light-pollution (accessed on 26 May 2020).

94. Petitions UK Government and Parliament. Available online: https://petition.parliament.uk/ (accessed on 26 May 2020).

95. Deutcher Bundestag Petitionen. Available online: https://epetitionen.bundestag.de/ (accessed on 26 May 2020).

96. Petition the EU. Available online: https:/ec.europa.eu/info/about-european-commission/get-involved/ petition-eu_en (accessed on 26 May 2020).

97. Flyvbjerg, B. Case Study. In The Sage Handbook of Qualitative Research, 4th ed.; Denzin, N.K., Lincoln, Y.S., Eds.; Sage: Thousand Oaks, CA, USA, 2011; Chapter 17; pp. 301-316.

98. Harvard Law School Student Studies Light Pollution Case Law for IDA. Available online: https://www.darksky. org/harvard-law-school-student-studies-light-pollution-case-law-for-ida/ (accessed on 26 May 2020).

99. The World's Platform for Change. Available online: www.change.org (accessed on 26 May 2020).

100. Light Up SWHS Turf Field! Available online: https://www.change.org/p/town-residents-light-up-swhs-turffield (accessed on 26 May 2020).

101. Light Up Mayon Volcano. Available online: https://www.change.org/p/department-of-tourism-light-upmayon-volcano (accessed on 26 May 2020).

102. Welcome to the Petitions Web Portal. Available online: https://petiport.secure.europarl.europa.eu/petitions/ en/home (accessed on 26 May 2020).

103. Schreier, M. Qualitative Content Analysis in Practice, 1st ed.; SAGE Publications Ltd.: London, UK, 2012.

104. Matthew, B.; Miles, M.B.; Huberman, A.M.; Saldaña, J. Qualitative Data Analysis. A Methods Sourcebook, 3rd ed.; SAGE Publications: Thousand Oaks, CA, USA; Los Angeles, CA, USA; London, UK; New Delhi, India; Singapore; Washington, DC, USA, 2013; ISBN 978-1-4522-5787-7.

105. Jarrell, S.B. Basic Statistics. William C Brown Communications: Dubuque, IA, USA, 1994.

106. Shanghai Man Wins Light Pollution Case. Available online: https://www.chinadaily.com.cn/english/doc/ 2004-11/02/content_387909.htm (accessed on 26 May 2020).

107. Describing Scatterplots (Form, Direction, Strength, Outliers). Available online: https://www.khanacademy. org/math/ap-statistics/bivariate-data-ap/scatterplots-correlation/a/describing-scatterplots-form-directionstrength-outliers (accessed on 12 June 2020).

108. ISO 3166 Country Codes. Available online: https://www.iso.org/iso-3166-country-codes.html (accessed on 26 May 2020).

109. Board of Education of Louisville v. Klein. Available online: https://casetext.com/case/board-of-education-oflouisville-v-klein?utm_source=Iterable\&utm_medium=email\&utm_campaign=prospecting-emails\&tab= keyword\&jxs=\&sort=relevance\&type $=$ case\&resultsNav=false (accessed on 26 May 2020).

110. National Parks \& Conservation Assn. v. County of Riverside. 1999. Available online: https:/law.justia.com/ cases/california/court-of-appeal/4th/71/1341.html (accessed on 26 May 2020).

111. Keep Our Street Lights Turned off. Available online: https://www.hertfordshire.gov.uk/about-thecouncil/freedom-of-information-and-council-data/open-data-statistics-about-hertfordshire/how-wemake-decisions/view-petition.aspx?Id=9eb7fa18-257f-4589-bcfa-bcd036f4e277 (accessed on 26 May 2020). 
112. Help Stop the Innocent Baby Sea Turtles from Dying in Florida! Light Pollution Is Dangerous. Available online: https:/www.change.org/p/help-stop-the-innocent-baby-sea-turtles-from-dying-in-florida-lightpollution-is-dangerous-because-they-kill-baby-sea-turtles (accessed on 26 May 2020).

113. Save Jax Beach Baby Sea Turtles from Certain Deaths Because of Artifical Light. Available online: https://www.change.org/p/mayor-charlie-latham-save-jacksonville-beach-baby-sea-turtles-fromcertain-death-because-of-artificial-light-on-our-beach (accessed on 26 May 2020).

114. How Petitions Work. Available online: https://petition.parliament.uk/help\#standards (accessed on 26 May 2020).

115. Hertfordshire County Council Petitions Scheme. Available online: https://www.hertfordshire.gov.uk/medialibrary/documents/about-the-council/data-and-information/constitution-annex-24-may-2019.pdf (accessed on 26 May 2020).

116. Arrêtez le Mauvais Usage de L'éclairage Public aux DEL Blanches qui Nuit à Notre Santé! Available online: https://www.change.org/p/trop-de-lumiere-c-est-pas-brillant-too-much-light-isn-t-too-bright (accessed on 26 May 2020).

117. Freedom to Choose Healthy Light! Available online: https://www.change.org/p/european-commission-sdirectorate-general-for-energy-freedom-to-choose-healthy-light (accessed on 26 May 2020).

118. Stop the Installation of Two LED Billboards in Lombard, IL. Available online: https://www.change.org/p/ stop-the-installation-of-two-led-billboards-in-lombard-il (accessed on 26 May 2020).

119. Space Night. Available online: https://www.change.org/p/president-of-the-united-states-space-night (accessed on 26 May 2020).

120. Fight Light Pollution in Surrey-Turn off Fountain Uplighting. Available online: https://www.change.org/p/ fight-light-pollution-in-surrey-turn-off-fountain-uplighting\$delimiter"026E30F\$ (accessed on 26 May 2020).

121. Petition No 1411/2015 by, U.N. (German) on Preventing Light Pollution and Taking Measures against it. Available online: https://petiport.secure.europarl.europa.eu/petitions/en/petition/content/1411\%252F2015/ html/Petition-No-1411\%252F2015-by-U.N.-\%2528German\%2529-on-preventing-light-pollution-andtaking-measures-against-it (accessed on 26 May 2020).

122. Put that Light Out. Available online: https://www.change.org/p/brighton-and-hove-albion-fc-put-that-light-out (accessed on 26 May 2020).

123. Light Dunedin Smartly. Available online: https://www.change.org/p/light-dunedin-smartly (accessed on 26 May 2020).

124. Are Ford Field's Blue Lights Polluting The Night Sky? Petition Seeks To Shut Down Roof Lighting. Available online: https://detroit.cbslocal.com/2017/02/10/are-ford-fields-blue-lights-polluting-the-night-sky-petitionseeks-to-shut-down-roof-lighting (accessed on 26 May 2020).

125. Île-Bizard Residents' Petition Puts LED Street Light Installation Project on Hold. Available online: https://globalnews.ca/news/6021460/ile-bizard-led-street-lights-petition/?fbclid=IwAR2SJ1iyYvyNsuIeS5MopUXlejeAJ0V-KeOkok5duSGdGzojnTAVYPiUDQ (accessed on 26 May 2020).

126. Artificial Light at Night (ALAN) Research Literature Database. Available online: http://alandb.darksky.org/ index.php (accessed on 26 May 2020).

127. Big Victory for Our Majestic Sea Turtles in Atlantic Beach FL! Available online: https://www.change.org/p/ help-stop-the-innocent-baby-sea-turtles-from-dying-in-florida-light-pollution-is-dangerous-because-theykill-baby-sea-turtles/u/22626558 (accessed on 26 May 2020).

128. City's LED Retrofit Shows Need for Careful Lighting Choices. Available online: https://www.darksky.org/ citys-led-retrofit-shows-need-for-careful-lighting-choices/ (accessed on 26 May 2020).

129. IDA Technical Committee. Available online: https:/www.darksky.org/about/board-of-directors/committees/ ida-technical-committee/ (accessed on 26 May 2020).

(C) 2020 by the authors. Licensee MDPI, Basel, Switzerland. This article is an open access article distributed under the terms and conditions of the Creative Commons Attribution (CC BY) license (http://creativecommons.org/licenses/by/4.0/). 